\title{
Management matters: testing a mitigation strategy for nitrous oxide emissions using legumes on intensively managed grassland
}

\author{
Kathrin Fuchs ${ }^{1}$, Lukas Hörtnagl ${ }^{1}$, Nina Buchmann ${ }^{1}$, Werner Eugster ${ }^{1}$, Val Snow ${ }^{2}$, and Lutz Merbold ${ }^{1,3}$ \\ ${ }^{1}$ Department of Environmental Systems Science, Institute of Agricultural Sciences, ETH Zurich, Universitätstrasse 2, \\ 8092 Zurich, Switzerland \\ ${ }^{2}$ AgResearch - Lincoln Research Centre, Private Bag 4749, Christchurch 8140, New Zealand \\ ${ }^{3}$ Mazingira Centre, International Livestock Research Institute (ILRI), P.O. Box 30709, 00100 Nairobi, Kenya
}

Correspondence: Kathrin Fuchs (kafuchs@ethz.ch)

Received: 16 April 2018 - Discussion started: 24 April 2018

Revised: 27 July 2018 - Accepted: 27 August 2018 - Published: 18 September 2018

\begin{abstract}
Replacing fertiliser nitrogen with biologically fixed nitrogen (BFN) through legumes has been suggested as a strategy for nitrous oxide $\left(\mathrm{N}_{2} \mathrm{O}\right)$ mitigation from intensively managed grasslands. While current literature provides evidence for an $\mathrm{N}_{2} \mathrm{O}$ emission reduction effect due to reduced fertiliser input, little is known about the effect of increased legume proportions potentially offsetting these reductions, i.e. by increased $\mathrm{N}_{2} \mathrm{O}$ emissions from plant residues and root exudates. In order to assess the overall effect of this mitigation strategy on permanent grassland, we performed an in situ experiment and quantified net $\mathrm{N}_{2} \mathrm{O}$ fluxes and biomass yields in two differently managed grassclover mixtures. We measured $\mathrm{N}_{2} \mathrm{O}$ fluxes in an unfertilised parcel with high clover proportions vs. an organically fertilised control parcel with low clover proportions using the eddy covariance (EC) technique over 2 years. Furthermore, we related the measured $\mathrm{N}_{2} \mathrm{O}$ fluxes to management and environmental drivers. To assess the effect of the mitigation strategy, we measured biomass yields and quantified biologically fixed nitrogen using the ${ }^{15} \mathrm{~N}$ natural abundance method.

The amount of BFN was similar in both parcels in 2015 (control: $55 \pm 5 \mathrm{~kg} \mathrm{Nha}^{-1} \mathrm{yr}^{-1}$; clover parcel: $72 \pm$ $5 \mathrm{~kg} \mathrm{~N} \mathrm{ha}^{-1} \mathrm{yr}^{-1}$ ) due to similar clover proportions (control: $15 \%$ and clover parcel: $21 \%$ ), whereas in $2016 \mathrm{BFN}$ was substantially higher in the clover parcel compared to the much lower control (control: $14 \pm 2 \mathrm{~kg} \mathrm{Nha}^{-1} \mathrm{yr}^{-1}$ with $4 \%$ clover in DM; clover parcel: $130 \pm 8 \mathrm{~kg} \mathrm{~N}^{-1} \mathrm{yr}^{-1}$ and $44 \%$ clover). The mitigation management effectively reduced $\mathrm{N}_{2} \mathrm{O}$ emissions by $54 \%$ and $39 \%$ in 2015 and 2016, respectively, corresponding to 1.0 and $1.6 \mathrm{tha}^{-1} \mathrm{yr}^{-1} \mathrm{CO}_{2}$ equiva-
\end{abstract}

lents. These reductions in $\mathrm{N}_{2} \mathrm{O}$ emissions can be attributed to the absence of fertilisation on the clover parcel. Differences in clover proportions during periods with no recent management showed no measurable effect on $\mathrm{N}_{2} \mathrm{O}$ emissions, indicating that the decomposition of plant residues and rhizodeposition did not compensate for the effect of fertiliser reduction on $\mathrm{N}_{2} \mathrm{O}$ emissions. Annual biomass yields were similar under mitigation management, resulting in a reduction of $\mathrm{N}_{2} \mathrm{O}$ emission intensities from $0.42 \mathrm{~g} \mathrm{~N}_{2} \mathrm{O}-\mathrm{N} \mathrm{kg}^{-1} \mathrm{DM}$ (control) to $0.28 \mathrm{~g} \mathrm{~N}_{2} \mathrm{O}-\mathrm{N} \mathrm{kg}^{-1} \mathrm{DM}$ (clover parcel) over the 2year observation period. We conclude that $\mathrm{N}_{2} \mathrm{O}$ emissions from fertilised grasslands can be effectively reduced without losses in yield by increasing the clover proportion and reducing fertilisation.

\section{Introduction}

Agricultural practices contribute $5.4 \mathrm{GtCO}_{2}$ eq. $\mathrm{yr}^{-1}$ (range $11 \%-12 \%)$ to global greenhouse gas (GHG) emissions (IPCC, 2014; Tubiello et al., 2015). The technical potential to mitigate $\mathrm{GHG}$ emissions from agriculture ranges between 5.5 and $6.0 \mathrm{GtCO}_{2}$ eq. $\mathrm{yr}^{-1}$ by 2030 (Smith et al., 2008), exceeding current agricultural GHG emissions. The three major anthropogenic GHGs are carbon dioxide $\left(\mathrm{CO}_{2}\right)$, methane $\left(\mathrm{CH}_{4}\right)$, and nitrous oxide $\left(\mathrm{N}_{2} \mathrm{O}\right)$. The agricultural sector is responsible for $84 \%$ of global anthropogenic $\mathrm{N}_{2} \mathrm{O}$ emissions (Smith et al., 2008). $\mathrm{N}_{2} \mathrm{O}$ emissions are primarily attributed to mineral and organic fertiliser applied to soils, manure left on pastures, biomass burning, crop residues, and in- 
creased mineralisation of soil organic matter (SOM) caused by the cultivation of soils (IPCC, 2014; Tubiello et al., 2015). Due to the high global warming potentials of $\mathrm{CH}_{4}$ and $\mathrm{N}_{2} \mathrm{O}$ (GWP; factor 34 and 298, respectively, on a per mass basis compared to $\mathrm{CO}_{2}$ based on a 100-year time horizon) (IPCC, $2013 \mathrm{~b}$ ), these gases are more important than the $\mathrm{CO}_{2}$ fluxes from the agricultural sector. However, they remain far less understood than $\mathrm{CO}_{2}$ fluxes because of interactions between multiple underlying processes that are largely unexplored. In particular, data resolving the dynamics of $\mathrm{N}_{2} \mathrm{O}$ fluxes from soils are still scarce, as advances in instruments capable of high-frequency continuous $\mathrm{N}_{2} \mathrm{O}$ concentration measurements that are steadily deployable in the field have only become available in recent years (Eugster and Merbold, 2015).

Here we test a potential mitigation strategy for nitrous oxide emissions, namely the substitution of fertiliser with biologically fixed nitrogen (BFN) via clover on intensively managed grassland. Processes producing and consuming $\mathrm{N}_{2} \mathrm{O}$ are numerous and their complex interactions and dependencies on biotic and abiotic factors are generally known but not yet fully understood (Butterbach-Bahl et al., 2013). Nevertheless, it is known that $\mathrm{N}_{2} \mathrm{O}$ emissions in grasslands strongly depend on management practices (Hörtnagl et al., 2018; Li et al., 2013; Snyder et al., 2009), and reducing $\mathrm{N}_{2} \mathrm{O}$ emissions while maintaining yields can thus contribute to climate smart agriculture (CSA) (Lipper et al., 2014). For mitigating $\mathrm{N}_{2} \mathrm{O}$ emissions from soils, a range of options (e.g. nitrification inhibitors, liming of acid soils, precision fertiliser use, legumes) are available (Bell et al., 2015; Flessa, 2012; de Klein and Eckard, 2008; Li et al., 2013; Luo et al., 2010; Paustian et al., 2016; Smith et al., 2008). The most important strategies focus on increasing the nitrogen use efficiency (NUE) of plants by adjusting the rate, type, timing, and placement of organic and inorganic nitrogen fertilisers. With such approaches, the surplus of nitrogen $(\mathrm{N})$ as the substrate for microbial communities producing $\mathrm{N}_{2} \mathrm{O}$ can be reduced or avoided (Flessa, 2012; Galloway et al., 2003; Snyder et al., 2009). Reducing N surplus comes along with other environmental benefits such as reduced ammonia emissions $\left(\mathrm{NH}_{3}\right)$ and nitrate $\left(\mathrm{NO}_{3}^{-}\right)$leaching, both potential sources of indirect (off-site) $\mathrm{N}_{2} \mathrm{O}$ emissions. Similar to these mitigation strategies, forage legume species of the Fabaceae family (e.g. white clover, red clover, lucerne, also called alfalfa) grown in grass-legume mixtures have the potential to reduce $\mathrm{N}_{2} \mathrm{O}$ emissions as a cost-effective mitigation strategy (Jensen et al., 2012). In legume-rich systems, large parts of the plants' nitrogen $(\mathrm{N})$ demand can be provided from the atmosphere via biological nitrogen fixation (BNF) instead of using fertiliser amendments (Ledgard et al., 2001; Suter et al., 2015). Hence, $\mathrm{N}$ input via BNF instead of fertilisers has the potential to avoid large $\mathrm{N}$ surpluses by provisioning $\mathrm{N}$ in a manner synchronous to plant needs following their growth pattern (Crews and Peoples, 2005). Furthermore, BNF is downregulated by the plant when demand is low; fixed $\mathrm{N}$ is located in the nodules and thus not freely available to microbiota in the soil (Lüscher et al., 2014; Nyfeler et al., 2011).

Our mitigation approach investigated the potential for reductions in slurry application accompanied by increased clover proportion in the pasture to reduce $\mathrm{N}_{2} \mathrm{O}$ emissions at the field scale. Farmers currently use a combination of homeproduced slurries and bought mineral fertiliser. Our suggestion is to apply the slurry to the fields which are amended with mineral fertiliser. This would have an additional benefit of reducing indirect GHG emissions, i.e. those during the manufacture of mineral fertilisers.

Besides the obvious advantage of lower fertiliser amendments, grass-legume mixtures typically achieve higher yields than average grass and legume monocultures ("overyielding effect") and often also higher yields than the best-performing monoculture ("transgressive overyielding"), with legume proportions of $40 \%-70 \%$ resulting in the highest yields (Finn et al., 2013; Lüscher et al., 2014; Nyfeler et al., 2009). In addition, growing selected legumes in mixtures with non-legumes could improve the resistance and resilience of forage swards against climatic extremes such as severe drought events (Hofer et al., 2017). Moreover, grass-legume mixtures are beneficial to fodder composition as they are characterised by higher protein contents than grass swards, and show well-balanced feeding values (Phelan et al., 2015). Legume-rich fodder has high crude protein (CP) contents and was shown to increase voluntary intake by $10 \%-20 \%$ (Dewhurst et al., 2003) and to increase milk production (Dewhurst et al., 2003; Huhtanen et al., 2007).

Despite the known advantages, introducing legumes causes some challenges for farmers. For instance, maintaining a persistent optimal legume proportion of 30\%-60\% (30 \%-50\%, Lüscher et al., 2014; $40 \%-60 \%$, Nyfeler et al., 2011) is not trivial (Guckert and Hay, 2001). Conservation of legumes such as hay or silage can be more difficult than for grasses due to lower contents of water-soluble carbohydrates (WSC) and higher $\mathrm{pH}$ buffering capacities (Phelan et al., 2015). When protein-rich forage is fed without sufficient WSC, $\mathrm{N}$ cannot be used efficiently by livestock and N excretion from the animals increases (Phelan et al., 2015). However, the balance between CP and WSC can be provided by carbohydrates from other plant species in mixtures (Lüscher et al., 2014). Furthermore, exceptionally high legume proportions $(>80 \%)$ and legume monocultures can lead to similar $\mathrm{N}$ surplus due to high levels of $\mathrm{BFN}$ as found in fertilised fields and consequently to high soil nitrate concentrations (Weisser et al., 2017), which can subsequently lead to enhanced $\mathrm{N}_{2} \mathrm{O}$ emissions (Jensen et al., 2012). So far, relatively few in situ measurements at plot scale have been carried out to investigate the effect of legumes and grass-legume mixtures on $\mathrm{N}_{2} \mathrm{O}$ emissions (e.g. studies by Klumpp et al., 2011; Virkajärvi et al., 2010; Schmeer et al., 2014; Niklaus et al., 2016; Li et al., 2011). The contribution of legumes to total field-scale $\mathrm{N}_{2} \mathrm{O}$ emissions was attributed to the decomposition of $\mathrm{N}$-rich plant residues and $\mathrm{N}$ from root exudates 
(Millar et al., 2004; Rochette and Janzen, 2005). Although it was shown that some Rhizobium species are able to produce $\mathrm{N}_{2} \mathrm{O}$ via rhizobial denitrification (O'Hara and Daniel, 1985; Rosen and Ljunggren, 1996), direct $\mathrm{N}_{2} \mathrm{O}$ emissions from $\mathrm{BNF}$ are negligible compared to $\mathrm{N}_{2} \mathrm{O}$ from denitrification rates for most investigated species and hence result in no significant effect on field-scale $\mathrm{N}_{2} \mathrm{O}$ emissions (GarciaPlazaola et al., 1993; Rochette and Janzen, 2005).

To date, experimental studies investigating year-round $\mathrm{N}_{2} \mathrm{O}$ exchange in grassland systems are scarce (Skinner et al., 2014), and measurements of high temporal resolution in grassland relying on fertiliser input versus grassland based on BFN are missing. Thus, the aim of this study was to test the $\mathrm{N}_{2} \mathrm{O}$ mitigation strategy of substituting $\mathrm{N}$ fertiliser with BFN by increasing the clover proportion in grassland. Therefore, we measured $\mathrm{N}_{2} \mathrm{O}$ exchange and productivity in two adjacent grassland parcels, one with an intensive "business as usual" management compared to a parcel for which fertiliser amendments were substituted by over-sowing clover. Our specific objectives were (1) to quantify $\mathrm{N}_{2} \mathrm{O}$ emissions from both parcels, (2) to identify the meteorological and soil chemical drivers of $\mathrm{N}_{2} \mathrm{O}$ emissions, and (3) to assess if substituting $\mathrm{N}$ fertiliser with $\mathrm{BFN}$ was an effective $\mathrm{N}_{2} \mathrm{O}$ mitigation strategy. We hypothesised considerably lower $\mathrm{N}_{2} \mathrm{O}$ emissions in the clover parcel, lower soil nutrient availability in the clover parcel (and thus no effect of legume proportions on $\mathrm{N}_{2} \mathrm{O}$ emissions), and hypothesised fertilisation to play the dominant role in driving $\mathrm{N}_{2} \mathrm{O}$ emissions in the control parcel. We further expected minor differences in grassland yield between the two parcels and, as a consequence, reduced $\mathrm{N}_{2} \mathrm{O}$ emission intensities in the clover parcel.

\section{Material and methods}

\subsection{Site description}

The experiment was set up at the Swiss FluxNet site Chamau (CH-Cha), located in the valley of the Reuss River on the Swiss Plateau, approximately $30 \mathrm{~km}$ southwest of Zurich $\left(47^{\circ} 12^{\prime} 36.8^{\prime \prime} \mathrm{N}, 8^{\circ} 24^{\prime} 37.6^{\prime \prime} \mathrm{E} ; 393 \mathrm{~m}\right.$ a.s.1.). The site has been well investigated in terms of $\mathrm{CO}_{2}$ exchange (Burri et al., 2014, using static chambers (SC); Zeeman et al., 2010, using EC), as well as for $\mathrm{N}_{2} \mathrm{O}$ and $\mathrm{CH}_{4}$ exchange under management that is typical for Swiss grasslands located on the Swiss Plateau (Imer et al., 2013, using SC for $\mathrm{N}_{2} \mathrm{O}$ and $\mathrm{CH}_{4}$ and $\mathrm{EC}$ for $\mathrm{CO}_{2}$; Merbold et al., 2014, using EC for all three gases; Wolf et al., 2015, using EC and SC for $\mathrm{N}_{2} \mathrm{O}$ ). Two grassland parcels of 2.2 and 2.7 ha are located adjacent to each other and have a similar management history, i.e. permanent grassland since at least 2002 with a restoration year in 2012 (Merbold et al., 2014). The most abundant species are English ryegrass (Lolium perenne) (a mixture of early and late varieties), common meadow grass (Poa pratensis), red fescue (Festuca rubra), timothy (Phleum pratense), white clover (Trifolium repens; small leaf varieties PEPSI, HEBE and big leaf varieties FIONA, BOMBUS), red clover (Trifolium pratense; variety BONUS) sown in 2012 and complemented by the volunteer species dandelion (Taraxacum officinale), and rough meadow grass (Poa trivialis). Each parcel is usually mown four to six times per year for silage or hay production (Table 1). Each harvest is commonly followed by a fertiliser amendment, predominantly in the form of liquid slurry (average \pm SD over 11 years (2003-2014) $\left.266 \pm 75 \mathrm{~kg} \mathrm{~N} \mathrm{ha}^{-1} \mathrm{yr}^{-1}\right)$.

The meteorological conditions at the site are characterised by an average annual temperature of $9.1^{\circ} \mathrm{C}$ and an average annual precipitation sum of $1151 \mathrm{~mm}$ (Sieber et al., 2011). The soil is a gleysol-cambisol, with bulk densities in $0-0.2 \mathrm{~m}$ of depth ranging between 0.9 and $1.3 \mathrm{~g} \mathrm{~cm}^{-3}$ (Roth, 2006) and a soil pH of about 6.5 (Labor Ins AG, Kerzers, Switzerland, in 2014).

\subsection{Experimental set-up and management activities}

The field experiment comprised a control and a clover treatment parcel (Fig. 1). The control parcel was managed similarly to previous years, including the common management activities described above (harvest, fertiliser application, and occasional grazing; Table 1). The eddy covariance tower, including meteorological sensors, was located at the border between the two parcels (Fig. 1). We used the two years 2013 and 2014 as reference years (no treatment). In order to test the $\mathrm{N}_{2} \mathrm{O}$ mitigation option, the treatment parcel was over-sown in March 2015 and April 2016 with clover (Trifolium pratense L. and two varieties of Trifolium repens L.) to increase the clover proportion of the sward in the clover parcel. In contrast to the control parcel on which 296 and $181 \mathrm{~kg} \mathrm{Nha}^{-1}$ were added in 2015 and 2016, respectively (Table 1), no fertiliser was applied on the clover parcel during the experiment. To assist clover establishment and increase the clover proportion in the clover parcel, the parcel was grazed with sheep after over-sowing in mid-June and the beginning of July 2015 to keep the grass species short and thus reduce competition during the clover establishment phase. The control parcel was mown once instead of being grazed during this time (beginning of July). All other harvests took place on the same day on both parcels (see Table 1 for specific management data including dates, slurry composition, and sowing rate).

Management activities comprised the regular harvest activities (mowing, swathering, and subsequent biomass removal) on both parcels, with subsequent slurry applications in the control parcel, besides occasional grazing, plus the over-sowing of the clover parcel. During our reference years 2013 and 2014, management was identical in both parcels in 2013, while in 2014 instead of mowing, cattle were grazing in the control parcel, whereas the clover parcel was mown, resulting in similar reference fluxes from both parcels. Yields and exports of $\mathrm{C}$ and $\mathrm{N}$ were quantified by 


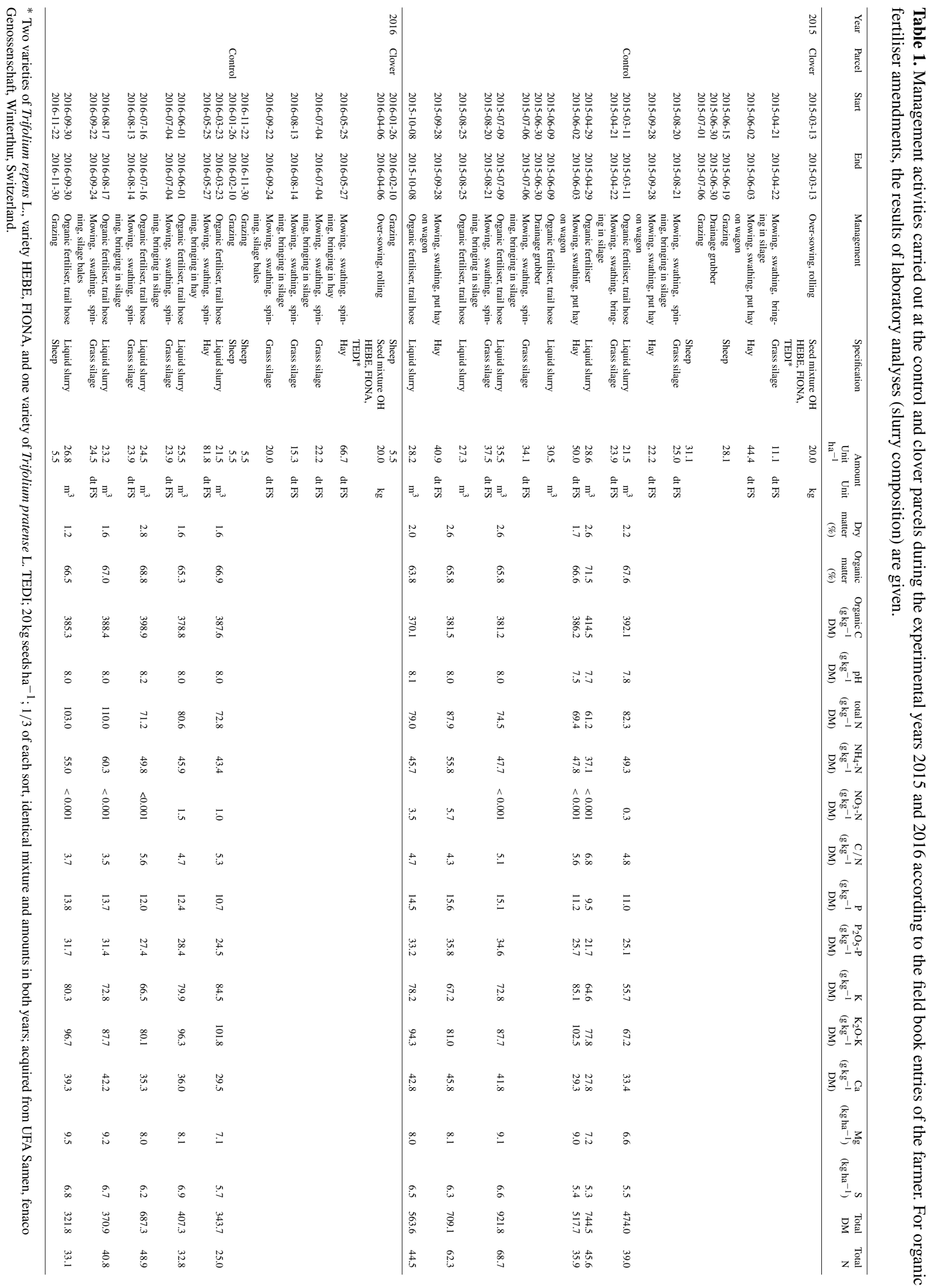




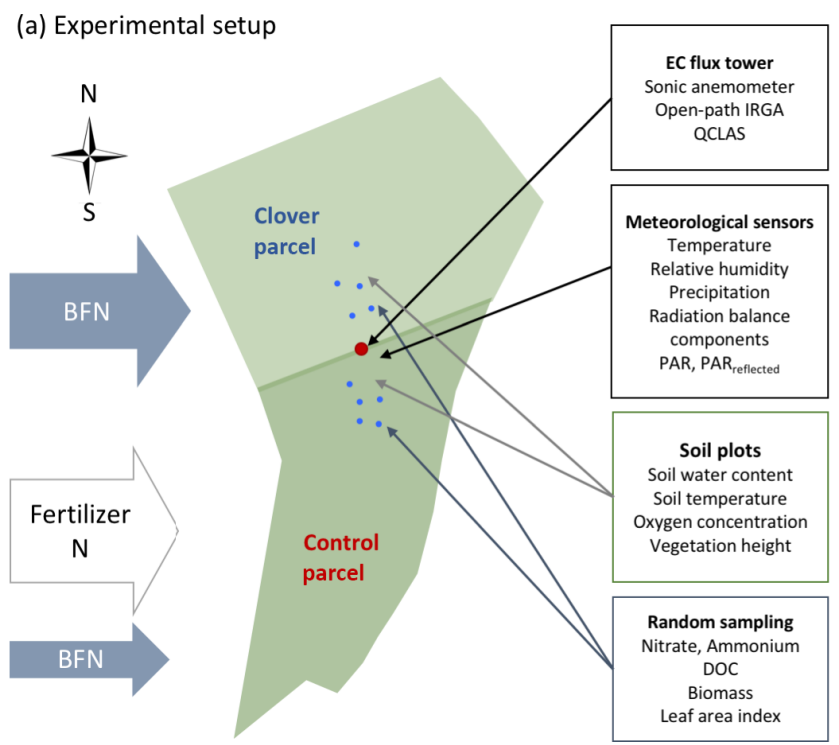

(b) Footprint climatology

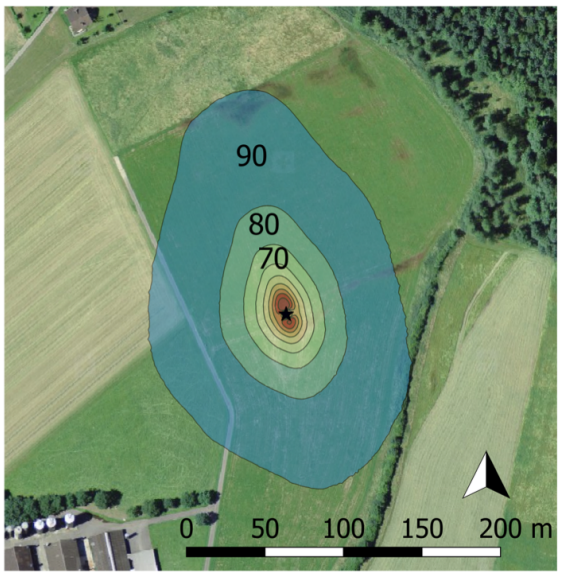

Figure 1. (a) Experimental set-up and measured variables at the experimental research site Chamau (CH-Cha). The clover parcel (north) is managed to increase nitrogen inputs from the atmosphere via increased biologically fixed nitrogen (BFN). This was achieved by over-sowing with clover in March 2015 and April 2016. In contrast, the control parcel under conventional management (south) obtains most $\mathrm{N}$ in the form of organic fertiliser (i.e. slurry) and only small $\mathrm{N}$ inputs via BNF. Blue dots represent soil sampling locations. (b) Footprint climatology of the years 2013-2016 with footprint contour lines of 10\% to $90 \%$ in 10\% steps using the Kljun et al. (2015) footprint model (background picture used with kind permission from Swisstopo, https://map.geo.admin.ch/, last access: 5 June 2018). The prevailing wind direction was from the north.

analysing biomass sampled destructively during each harvest event (see Sect. 2.7 on vegetation samples) for $\mathrm{C}$ and $\mathrm{N}$ contents in the years 2015-2016. The fraction of $\mathrm{N}$ originating from BNF in the harvested biomass (2015-2016) was quantified via the ${ }^{15} \mathrm{~N}$ natural abundance method (Unkovich, 2008). Combined with the legume biomass obtained by destructive biomass sampling at all harvest dates, we were able to calculate the total amounts of BFN in the harvested biomass. Beyond our own observations, detailed management information for the years 2001-2016 was recorded by the farm staff in a field book. The overall amount of organic and mineral fertiliser applied to the field was documented, and subsamples of the applied slurry were taken on the day of application (since 2007) and analysed in an external laboratory (LBU, Eric Schweizer AG, Thun, Switzerland). Slurry applied to the control parcel was digested cattle and pig slurry obtained from a local biogas plant (for chemical composition, see Table 1). Records in the field book also included information on herbicide application, harrowing, rolling, and over-sowing (for details, see Table 1).

\subsection{Greenhouse gas flux measurements}

Greenhouse gas exchange $\left(\mathrm{CO}_{2}, \mathrm{~N}_{2} \mathrm{O}, \mathrm{CH}_{4}, \mathrm{H}_{2} \mathrm{O}\right)$ was continuously measured at the site with the eddy covariance (EC) technique using a mast located at the boundary between the two parcels (Fig. 1). The choice of the EC tower location resulted in the fetch being located most of the time either in one or the other parcel, taking advantage of the two prevailing wind directions. The flux measurement set-up consisted of a 3-D sonic anemometer (Solent R3, Gill Instruments, Lymington, UK), an open-path infrared gas analyser for $\mathrm{CO}_{2}$ and $\mathrm{H}_{2} \mathrm{O}$ concentrations (LI-7500, LI-COR Biosciences, Lincoln, NE, USA), and a quantum cascade laser absorption spectrometer (QCLAS) capable of measuring $\mathrm{N}_{2} \mathrm{O}, \mathrm{CH}_{4}$, and $\mathrm{H}_{2} \mathrm{O}$ concentrations (mini-QCLAS, Aerodyne Research Inc., Billerica, MA, USA) (Merbold et al., $2014)$ at $10 \mathrm{~Hz}$ resolution. The air inlet for the laser absorption spectrometer was located at a height of $2.1 \mathrm{~m}$, just below the sonic anemometer head. The air was pulled through a $6 \mathrm{~m}$ long tube to the QCLAS located in a temperaturecontrolled weatherproof box. Data acquisition and data storage were conducted according to the set-up described in Eugster and Plüss (2010). From the high-frequency measurements of these sensors, 10 and 30 min flux averages of the respective trace gases were calculated. The basic EC system, measuring $\mathrm{CO}_{2}$ and $\mathrm{H}_{2} \mathrm{O}$ exchange, has been running since 2005 (Eugster and Zeeman, 2006; Zeeman et al., 2010) and was complemented with the field-suitable QCLAS for highfrequency $(10 \mathrm{~Hz}) \mathrm{N}_{2} \mathrm{O}$ concentration measurements in 2012 (Merbold et al., 2014). Thus, more than 2 years of reference fluxes from both parcels under similar management regimes were collected before the beginning of the study presented here. 


\subsection{Meteorological and soil microclimate measurements}

Meteorological variables measured at the Chamau site included air temperature and relative humidity ( $2 \mathrm{~m}$ of height; Hydroclip S3 sensor, Rotronic AG, Switzerland), all components of the radiation balance ( $2 \mathrm{~m}$ of height; CNR1, Kipp \& Zonen B.V., Delft, the Netherlands), incoming and reflected photosynthetic active radiation ( $2 \mathrm{~m}$ of height; PARlite sensor, Kipp and Zonen, Delft, the Netherlands), and precipitation ( $1 \mathrm{~m}$ of height; tipping bucket rain gauge model 10116, Toss GmbH, Potsdam, Germany) (Table S1 in the Supplement, Fig. 1). Less than $2 \mathrm{~m}$ from the tower, basic soil microclimate measurements were carried out. These measurements included volumetric soil water content (at 0.04 and $0.15 \mathrm{~m}$ of depth; ML2x sensors, Delta-T Devices Ltd., Cambridge, UK) and soil temperature (at 0.01, 0.02, 0.05, 0.10, and $0.15 \mathrm{~m}$ of depth; TL107 sensors, Markasub AG, Olten, Switzerland). In addition to the sensors close to the tower, each parcel was equipped with a similar set of soil sensors in 2015 (see soil plots, Fig. 1) to compare potential differences in soil microclimatic conditions and subsequent effects on GHG fluxes. Soil $\mathrm{pH}$ (at $0.1 \mathrm{~m}$ of depth) and soil oxygen $\left(\mathrm{O}_{2}\right)$ concentration (at $0.1,0.2 \mathrm{~m}$ of depth) were automatically measured using in-house custom-made sensors (based on ISFET $\mathrm{pH}$ sensor kit, Sentron, Roden, Netherlands and EC410 oxygen sensors, SGX Sensortech, Chelmsford, UK). In addition, soil water content (at 0.05, 0.1, 0.2, 0.5, $0.8 \mathrm{~m}$ of soil depth; EC-5, Decagon, Pullman, WA, USA), soil temperature (at $0.05,0.1,0.2,0.5,0.8 \mathrm{~m}$ of soil depth; T109, Campbell Scientific Inc., Logan, UT, USA), matrix potential (at $0.1,0.2 \mathrm{~m}$ of soil depth; Tensiometer T8, UMS $\mathrm{GmbH}$, Munich, Germany), and soil heat flux (at $0.02 \mathrm{~m}$ of soil depth; HFP01, Hukseflux B.V., Delft, Netherlands) were recorded. Some of the soil water content sensors stopped functioning on 18 June 2015 (at 0.05, 0.1, 0.2 m) and were thus replaced on 6 August 2015 (Decagon 5TM, Pullman, WA, USA). The signals of these sensors were sampled at $10 \mathrm{~s}$ intervals and stored as $10 \mathrm{~min}$ averages on a data logger (CR1000; Campbell Scientific Inc., Logan, USA). Sensors at the tower and in its vicinity were previously connected to a CR10X model (Campbell Scientific Inc., Logan, USA) and since March 2016 to a newer data logger (CR1000; Campbell Scientific Inc., Logan, USA).

\subsection{Soil nutrient availability}

For determining ammonium $\left(\mathrm{NH}_{4}^{+}\right)$, nitrate $\left(\mathrm{NO}_{3}^{-}\right)$, and dissolved organic carbon (DOC) concentrations in the soil, topsoil samples were taken down to $0.2 \mathrm{~m}$ of depth. The nominally biweekly sampling was intensified to daily intervals for seven consecutive days following slurry application (see also Wolf et al., 2015). Five samples per parcel were taken along a transect within the average footprint of the EC measurements. Extraction of $\mathrm{NH}_{4}^{+}, \mathrm{NO}_{3}^{-}$, and $\mathrm{DOC}$ was achieved by shaking $15 \mathrm{~g}$ of fresh soil with $50 \mathrm{~mL} 0.5 \mathrm{M} \mathrm{K}_{2} \mathrm{SO}_{4}$ for $1 \mathrm{~h}$ and subsequent filtering (Whatman no. 42 ashless filter paper, $150 \mathrm{~mm}$ diameter, GE Healthcare AG, Glattbrugg, Switzerland) into centrifuge tubes $(50 \mathrm{~mL}$ tubes, $\mathrm{PP}$, Greiner Bio-One GmbH, St. Gallen, Switzerland). From the extract, a subsample was acidified for the measurement of DOC by combustion in a total organic $\mathrm{C}$ and $\mathrm{N}$ analyser (multi N/C TOC analyser 2100S, Analytik Jena AG, Jena, Germany). $\mathrm{NH}_{4}^{+}$and $\mathrm{NO}_{3}^{-}$were analysed colourimetrically (Vis V-1200, VWR International, Radnor, PA, USA). Thereafter, the remaining soil samples were dried for 1 week at $105^{\circ} \mathrm{C}$ and weighed before and after drying in order to determine the gravimetric soil water content.

\subsection{Vegetation sampling and determination of biological nitrogen fixation}

Vegetation samples were taken from each parcel at each harvest date by destructive sampling using harvest frames $\left(0.1 \mathrm{~m}^{2} ; n=10\right.$ for each parcel per date randomly sampled within the EC footprint clipped at a mowing height of $0.05 \mathrm{~m}$; Table S1). Vegetation was separated into legumes and nonlegumes (grasses and forbs) to assess the legume proportion in the dry biomass. The only legume species found on site were the sown clover species Trifolium pratense L. and Trifolium repens $\mathrm{L}$. Vegetation samples were dried at $70^{\circ} \mathrm{C}$ for 1 week and weighed before and after drying to estimate the water content. Milling of dry biomass samples was done separately for legumes and non-legumes, and a subsample of $5 \mathrm{mg}$ was weighed into tin capsules for further analyses of total $\mathrm{C}, \mathrm{N}, \delta^{13} \mathrm{C}$, and $\delta^{15} \mathrm{~N}$ ( $n=5$ for each parcel per date). $\mathrm{C}$ and $\mathrm{N}$ concentrations, as well as $\delta^{13} \mathrm{C}$ and $\delta^{15} \mathrm{~N}$ values, were analysed with a Flash EA 1112 series elemental analyser (Thermo Italy, former CE Instruments, Rhodano, Italy) coupled to an isotope ratio mass spectrometer (DELTAplusXP, Finnigan MAT, Bremen, Germany). Estimates of BFN were based on the $\delta^{15} \mathrm{~N}$ measurement. The percentage of shoot $\mathrm{N}$ derived from $\mathrm{BNF}\left(\% \mathrm{~N}_{\mathrm{dfa}}\right.$; nitrogen derived from the atmosphere) in legume biomass was calculated with the ${ }^{15} \mathrm{~N}$ natural abundance method (Boddey et al., 2000; Unkovich, 2008), following Eq. (1):

$\% \mathrm{~N}_{\mathrm{dfa}}=\frac{\left(\delta^{15} \mathrm{~N}_{\mathrm{ref}}-\delta^{15} \mathrm{~N}_{\text {legume }}\right)}{\left(\delta^{15} \mathrm{~N}_{\mathrm{ref}}-B\right)} \times 100$,

where $\% \mathrm{~N}_{\mathrm{dfa}}$ is the percentage of legume shoot $\mathrm{N}$ derived from the atmosphere, $\delta^{15} \mathrm{~N}_{\text {ref }}$ is the $\delta^{15} \mathrm{~N}$ value of a nonfixing reference plant (i.e. grass species) growing in the proximity of the legume, and $\delta^{15} \mathrm{~N}_{\text {legume }}$ is the $\delta^{15} \mathrm{~N}$ value of the legume shoot. The $B$ value is the $\delta^{15} \mathrm{~N}$ signature of the legume species growing without $\mathrm{N}$ available from soil. $B$ was estimated as the weighted mean of $B$ values of Trifolium repens $\mathrm{L}$. reported in the literature $(-1.48 \times 2 / 3)$ and Trifolium pratense $\mathrm{L}$. $(-0.94 \times 1 / 3)$ ( $B$ values from Unkovich, 2008, Appendix 4). Weights were chosen according to the sown legume species composition of $2 / 3$ white clover and 
Table 2. Characteristics of the exported biomass from the control and clover parcels in 2015 and 2016 for legumes, non-legumes, and total biomass (legumes and non-legumes). Numbers in brackets give the respective standard errors. The legume proportion is based on the annual biomass exported. $\mathrm{C}$ and $\mathrm{N}$ content and $\delta^{15} \mathrm{~N}$ values refer to mean values across all samples. BFN refers to $\mathrm{N}$ derived from the atmosphere in harvested clover biomass. Means sharing the same superscript (per row) are not significantly different from each other (Tukey's HSD, $p<0.05$ ); no significance tests were applied for percentages and ratios.

\begin{tabular}{|c|c|c|c|c|c|}
\hline \multirow[t]{2}{*}{ Variable (unit) } & & \multicolumn{2}{|c|}{2015} & \multicolumn{2}{|c|}{2016} \\
\hline & & Control & Clover & Control & Clover \\
\hline Biomass export (DM tha $\left.{ }^{-1}\right)$ & Total & $12.8( \pm 0.5)^{\mathrm{a}}$ & $10.4( \pm 0.7)^{\mathrm{b}}$ & $11.9( \pm 0.4)^{\mathrm{ab}}$ & $11.0( \pm 0.5)^{\mathrm{ab}}$ \\
\hline \multirow[t]{2}{*}{ Biomass export (DM kg ha-1) } & Legumes & $1860( \pm 176)^{\mathrm{a}}$ & $2240( \pm 141)^{b}$ & $503( \pm 80)^{\mathrm{ab}}$ & $4840( \pm 355)^{\mathrm{ab}}$ \\
\hline & Non-legumes & $11000( \pm 541)^{\mathrm{a}}$ & $8170( \pm 666)^{b}$ & $11400( \pm 462)^{\mathrm{a}}$ & $6150( \pm 493)^{\mathrm{b}}$ \\
\hline Legume proportion (\%) & Total & $15( \pm 12)$ & $21( \pm 8)$ & $4( \pm 5)$ & $44( \pm 20)$ \\
\hline \multirow{2}{*}{$\mathrm{C}$ content $(\%)$} & Legumes & $45.3( \pm 1.1)$ & $45.6( \pm 0.3)$ & $42.9( \pm 0.9)$ & $43.8( \pm 0.6)$ \\
\hline & Non-legumes & $45.1( \pm 1.4)$ & $45.2( \pm 0.4)$ & $43.0( \pm 1.0)$ & $43.0( \pm 1.0)$ \\
\hline \multirow[t]{2}{*}{$\mathrm{N}$ content $(\%)$} & Legumes & $3.36( \pm 0.24)$ & $3.56( \pm 0.14)$ & $3.30( \pm 0.14)$ & $3.08( \pm 0.18)$ \\
\hline & Non-legumes & $2.18( \pm 0.12)$ & $2.25( \pm 0.16)$ & $1.94( \pm 0.19)$ & $1.85( \pm 0.17)$ \\
\hline \multirow[t]{2}{*}{$\delta^{15} \mathrm{~N}(\% o)$} & Legumes & $-0.47( \pm 0.54)$ & $-0.72( \pm 0.21)$ & $-0.37( \pm 0.55)$ & $-0.76( \pm 0.24)$ \\
\hline & Non-legumes & $4.77( \pm 0.83)$ & $4.48( \pm 0.42)$ & $5.10( \pm 0.94)$ & $3.45( \pm 0.55)$ \\
\hline \multirow[t]{3}{*}{$\mathrm{C}\left(\mathrm{kg} \mathrm{ha}^{-1}\right)$} & Total & $5780( \pm 222)^{\mathrm{a}}$ & $4720( \pm 289)^{b}$ & $5120( \pm 221)^{\mathrm{ab}}$ & $4760( \pm 228)^{b}$ \\
\hline & Legumes & $843( \pm 78)^{\mathrm{a}}$ & $1020( \pm 70)^{\mathrm{a}}$ & $216( \pm 24)^{b}$ & $2120( \pm 123)^{\mathrm{c}}$ \\
\hline & Non-legumes & $4940( \pm 235)^{\mathrm{a}}$ & $3700( \pm 295)^{b}$ & $4900( \pm 220)^{\mathrm{a}}$ & $2640( \pm 275)^{\mathrm{c}}$ \\
\hline \multirow[t]{3}{*}{$\mathrm{N}\left(\mathrm{kg} \mathrm{ha}^{-1}\right)$} & Total & $301( \pm 10)^{\mathrm{a}}$ & $264( \pm 13)^{b}$ & $238( \pm 13)^{\mathrm{ab}}$ & $262( \pm 8)^{b}$ \\
\hline & Legumes & $63( \pm 6)^{\mathrm{a}}$ & $80( \pm 5)^{\mathrm{a}}$ & $17( \pm 2)^{b}$ & $149( \pm 9)^{\mathrm{c}}$ \\
\hline & Non-legumes & $238( \pm 9)^{\mathrm{a}}$ & $184( \pm 13)^{\mathrm{a}}$ & $221( \pm 11)^{\mathrm{a}}$ & $113( \pm 9)^{\mathrm{a}}$ \\
\hline BFN $\left(\mathrm{kg} \mathrm{ha}^{-1}\right)$ & Legumes & $55( \pm 5)^{\mathrm{a}}$ & $72( \pm 5)^{\mathrm{a}}$ & $14( \pm 2)^{b}$ & $130( \pm 8)^{\mathrm{c}}$ \\
\hline
\end{tabular}

$1 / 3$ red clover. The $\% \mathrm{~N}_{\mathrm{dfa}}$ in legume shoots was calculated for each legume biomass sample taken. The non-legumes cut within the same harvest frame as the legumes were used as a reference, delivering the $\delta^{15} \mathrm{~N}_{\text {ref }}$ value (Carlsson and HussDanell, 2014). For annual values, harvests, and their components, uncertainty estimates were calculated with the Gauss uncertainty propagation (Table 2). Vegetation development was tracked via leaf area index (LAI) measurements (LAI2000, LI-COR Biosciences, Lincoln, NE, USA) carried out on both parcels biweekly as well as before and after mowing or grazing activities. Vegetation height and plant development as well as grazing activities within the footprint were further monitored via standard webcams (IN-5907HD, INSTAR Deutschland GmbH, Huenstetten, Germany).

\subsection{Eddy covariance flux post-processing}

Net ecosystem fluxes of $\mathrm{CO}_{2}, \mathrm{~N}_{2} \mathrm{O}$, and $\mathrm{CH}_{4}$ were quantified by the eddy covariance (EC) method as the covariance between turbulent fluctuations calculated by Reynolds averaging $10 \mathrm{~min}$ blocks of data of vertical wind speeds and trace gas molar densities $\left(\mathrm{CO}_{2}\right)$ or mixing ratios $\left(\mathrm{N}_{2} \mathrm{O}, \mathrm{CH}_{4}\right)$. Molar densities of $\mathrm{CO}_{2}$ were corrected for water vapour transfer effects (Webb et al., 1980). Frequency response corrections applied to raw fluxes accounted for high-pass (Moncrieff et al., 2004) and low-pass filtering $\left(\mathrm{CO}_{2}\right.$ : Horst (1997); $\mathrm{N}_{2} \mathrm{O}$ and $\mathrm{CH}_{4}$ : Fratini et al. (2012). $\mathrm{N}_{2} \mathrm{O}$ and $\mathrm{CH}_{4}$ fluxes were additionally corrected for spectral losses due to instrument separation (Horst and Lenschow, 2009). All fluxes were calculated using the EddyPro software (v6.1.0, LI-COR Inc., Lincoln, NE, USA).

Before flux calculations, the statistical quality of the raw time series was checked (Vickers and Mahrt, 1997). Raw high-frequency data used in flux calculations were rejected (1) if raw measurements were outside a physically plausible range (vertical wind speed: $\pm 5 \mathrm{~m} \mathrm{~s}^{-1} ; \mathrm{CO}_{2}: 200$ to $900 \mathrm{ppm}$, $\mathrm{N}_{2} \mathrm{O}$ : below $250 \mathrm{ppb}, \mathrm{CH}_{4}$ : below $1700 \mathrm{ppb}$ ), (2) if spikes, defined as data points outside predefined sigma $(\sigma)$ plausibility ranges (vertical wind speed: $\pm 5 \sigma, \mathrm{CO}_{2}: \pm 3.5 \sigma, \mathrm{N}_{2} \mathrm{O}$ and $\mathrm{CH}_{4}: \pm 8 \sigma$ ), accounted for more than $1 \%$ of the respective raw time series, or (3) if more than $10 \%$ of available raw data were statistically different from the overall trend in a specific $10 \mathrm{~min}$ period. Raw $\mathrm{CO}_{2}$ measurements were only used for flux calculations if the window dirtiness signal from the open-path infrared gas analyser did not exceed $80 \%$ on average per 10 min data block. Half-hourly fluxes were rejected (1) if fluxes were outside predefined ranges $\left(\mathrm{CO}_{2}: \pm 50 \mu \mathrm{mol} \mathrm{m}^{-2} \mathrm{~s}^{-1} ; \mathrm{N}_{2} \mathrm{O}\right.$ : between -50 and $100 \mathrm{nmol} \mathrm{m}^{-2} \mathrm{~s}^{-1} ; \mathrm{CH}_{4}$ : between -400 and $800 \mathrm{nmol} \mathrm{m}^{-2} \mathrm{~s}^{-1}$ ), (2) if the steady-state test (Foken and Wichura, 1996) was outside $\pm 30 \%$, or (3) if the test on developed turbulent conditions was outside $\pm 30 \%$ (Foken et al., 2004; Foken and Wichura, 1996). The analytical flux footprint model by Kljun et al. (2015) was used for footprint calculations. 
The boundary between the two parcels is oriented approximately in the east-west direction ( $75^{\circ}$ from north; Fig. 1). Each 10 min flux average was attributed to a parcel only if a minimum of $80 \%$ of the flux footprint was in the direction of the respective parcel (i.e. footprint weights from the direction of the respective parcel divided by the total of all flux footprint weights $>80 \%$ ). Similar methods with EC fluxes from one set-up being attributed to certain land use categories according to the respective footprint area were successfully used before (e.g. Biermann et al., 2014; Gourlez de la Motte et al., 2018; Neftel et al., 2008; Rogiers et al., 2005; Sintermann et al., 2011). After quality control, data coverage for $\mathrm{N}_{2} \mathrm{O}$ exchange for both years was $62 \%$ of the entire period (details in Table 3). We observed moderate diurnal variations in flux origin from the two parcels (Fig. S2 in the Supplement). Nevertheless, a similar share of qualitycontrolled $\mathrm{N}_{2} \mathrm{O}$ fluxes was obtained from the control (48\%) and the clover parcel (52\%) during the observation period. The net effect in $\mathrm{N}_{2} \mathrm{O}$ emission differences represents a conservative estimate, as $\mathrm{N}_{2} \mathrm{O}$ emissions from the clover parcel are more likely to be overestimated and fluxes from the control parcel are more likely to be slightly underestimated (Fig. S2). Our aim was to analyse flux data originating from either one or the other parcel and avoid mixed GHG fluxes due to wind direction changes during the flux-averaging interval. As the standard $30 \mathrm{~min}$ averaging interval often resulted in mixed flux signals, we reduced the averaging period to $10 \mathrm{~min}$, which resulted in a clearer representation of the temporal dynamics of GHG fluxes from each individual parcel. On grassland systems in flat terrain (such as the Chamau site), eddies with a timescale of $1-5 \mathrm{~min}$ are dominant, and thus fluxes based on a $10 \mathrm{~min}$ averaging interval adequately represent the atmospheric exchange of GHGs (Lenschow et al., 1994). Our comparison of flux data (full time series) based on 10 and $30 \mathrm{~min}$ averaging intervals showed that the average of 10 min $\mathrm{N}_{2} \mathrm{O}$ fluxes was only $2.3 \%$ lower than the 30 min $\mathrm{N}_{2} \mathrm{O}$ fluxes. Daily averages were calculated based on all data points per parcel that fulfilled quality criteria 0 (best quality fluxes) or 1 (fluxes suitable for general analysis such as annual budgets) (Mauder and Foken, 2004).

\subsection{Comparison of $\mathrm{N}_{2} \mathrm{O}$ fluxes between parcels}

We applied non-parametric bootstrapping in order to estimate the mean annual $\mathrm{N}_{2} \mathrm{O}$ fluxes from both parcels and their respective confidence intervals. From all available $10 \mathrm{~min}$ fluxes, we took 1000 bootstrapping samples of each day per parcel. Averaging over time results in the bootstrapping estimate of the average annual flux, while the 0.025 and 0.975 percentiles of the bootstrapping distribution reveal the $95 \%$ confidence intervals for the mean flux per parcel.

Relative flux differences between parcels were defined as the difference of daily averages between clover and control parcels with respect to the average flux from the control, calculated based on all days for which data from both parcels were available. This was done to minimise potential biases associated with periods of unequal coverage of both parcels. Calculations were done following Eq. (2).

$\Delta F / F=\frac{\overline{F_{\text {Clover }}}-\overline{F_{\text {Control }}}}{\overline{F_{\text {Control }}}}$

$F_{\text {Clover }}$ and $F_{\text {Control }}$ are daily average fluxes from the clover and the control parcels, respectively. Before being able to identify differences in $\mathrm{N}_{2} \mathrm{O}$ exchange during the experimental periods, 2 years of flux data (2013 and 2014) were used to quantify how much the fluxes and the productivity from the two parcels deviated under exactly the same (2013) and similar (2014) management practice. For the calculation of $\mathrm{CO}_{2}$ equivalents $\left(\mathrm{CO}_{2}\right.$ eq.) we used factor 298 , which is the current IPCC global warming potential including climatecarbon feedbacks on a 100-year basis (IPCC, 2013a).

\subsection{Management and rain-event-specific $\mathrm{N}_{2} \mathrm{O}$ exchange}

Three management event types and one natural event type were analysed in more detail. These included organic fertiliser application, harvesting (mowing), sheep grazing, and rain events following dry weeks. When fertilisation took place less than 7 days after harvest, days after fertilisation were classified as fertilisation and thus not associated with the harvest event. If days after harvest overlapped days before fertilisation, these days were excluded from the fertilisation class. In this case, the data displayed and analysed only refer to days after harvest but not to days before fertilisation in order to avoid misleading references. A rain event was defined with $>4 \mathrm{~mm}$ precipitation following a dry period with $<1.5 \mathrm{~mm}$ collected during the 7 days preceding the rain event. When a fertilisation event took place at the same time as the rain event (9 August 2015 and 16 July 2016), the event was classified as a fertilisation event but not as a rain event. Grazing overlapped a rain event on 15 June and 1 July 2015, and thus these days were excluded from the rain event analysis. A pre-analysis was conducted for all these events, comparing $\mathrm{N}_{2} \mathrm{O}$ emissions during 7 days before the event to 7 days after the start of the event (incl. starting date). Grazing showed no significant differences between emissions before and during grazing, nor did rain events. These categories were therefore not considered in the generalised additive model (GAM; see Sect. 2.11).

\subsection{Statistical analysis}

In order to assess the influence of management and environmental drivers of $\mathrm{N}_{2} \mathrm{O}$ fluxes, we used semi-parametric generalised additive modelling (Wood, 2006). We expected non-linear effects of some predictor variables on $\mathrm{N}_{2} \mathrm{O}$ emissions, such as soil water content and oxygen concentration. The GAM is adequate for including these non-linear effects because it prescribes no parametric relationship between predictors and the response variable. Instead, the model fits 
Table 3. Data availability of the GHG flux measurements over the 2-year experimental period (a) before quality assessment and quality control (QAQC) (flagged 0, 1, and 2; after Foken et al., 2004) and (b) after QAQC (acceptable quality flagged 0 and 1; after Foken et al., 2004). The reference for $100 \%$ is a year without data gaps.

\begin{tabular}{|c|c|c|c|c|c|c|c|}
\hline \multirow[t]{2}{*}{ (a) } & & \multicolumn{3}{|c|}{$\begin{array}{l}\text { Acquired measurement hours } \\
\text { before QAQC }(\mathrm{h})\end{array}$} & \multicolumn{3}{|c|}{$\begin{array}{c}\text { Data coverage before QAQC } \\
(\%)\end{array}$} \\
\hline & & $\mathrm{CO}_{2}$ flux & $\mathrm{N}_{2} \mathrm{O}$ flux & $\mathrm{CH}_{4}$ flux & $\mathrm{CO}_{2}$ flux & $\mathrm{N}_{2} \mathrm{O}$ flux & $\mathrm{CH}_{4}$ flux \\
\hline \multirow[t]{3}{*}{2015} & Both parcels & 6958 & 7969 & 7964 & 79 & 91 & 91 \\
\hline & Control parcel & 4089 & 4826 & 4823 & 47 & 55 & 55 \\
\hline & Clover parcel & 2869 & 3143 & 3141 & 33 & 36 & 36 \\
\hline \multirow[t]{3}{*}{2016} & Both parcels & 7456 & 7734 & 7734 & 85 & 88 & 88 \\
\hline & Control parcel & 3911 & 4485 & 4485 & 45 & 51 & 51 \\
\hline & Clover parcel & 2302 & 2518 & 2518 & 26 & 29 & 29 \\
\hline \multirow[t]{2}{*}{ (b) } & & \multicolumn{3}{|c|}{$\begin{array}{l}\text { Acquired measurement hours } \\
\text { after QAQC (h) }\end{array}$} & \multicolumn{3}{|c|}{$\begin{array}{c}\text { Data coverage after QAQC } \\
(\%)\end{array}$} \\
\hline & & $\mathrm{CO}_{2}$ flux & $\mathrm{N}_{2} \mathrm{O}$ flux & $\mathrm{CH}_{4}$ flux & $\mathrm{CO}_{2}$ flux & $\mathrm{N}_{2} \mathrm{O}$ flux & $\mathrm{CH}_{4}$ flux \\
\hline \multirow[t]{3}{*}{2015} & Both parcels & 4930 & 5984 & 5223 & 56 & 68 & 60 \\
\hline & Control parcel & 1418 & 2120 & 1837 & 16 & 24 & 21 \\
\hline & Clover parcel & 2298 & 2395 & 2091 & 26 & 27 & 24 \\
\hline \multirow[t]{3}{*}{2016} & Both parcels & 3787 & 5040 & 4250 & 43 & 58 & 49 \\
\hline & Control parcel & 1081 & 1895 & 1581 & 12 & 22 & 18 \\
\hline & Clover parcel & 1548 & 1921 & 1615 & 18 & 22 & 18 \\
\hline
\end{tabular}

smoothing splines (piecewise defined polynomials) to the relationship between each predictor and the response variable, allowing for highly flexible curves if needed (i.e. if improving the goodness of fit), but resulting in the smoothest possible relationship (i.e. linear relationship) if suitable. The response variable was predicted by the sum of all these smooth functions ("additive"). The degree of smoothing for each additive function was determined using generalised crossvalidation (GCV).

The response variable was the log-transformed $\mathrm{N}_{2} \mathrm{O}$ flux in order to better meet the assumptions of normally distributed residuals. The additive model with a log-transformed response corresponds to a model with multiplicative effects in the original scale. Thus, the predictors' effects influence $\mathrm{N}_{2} \mathrm{O}$ fluxes multiplicatively. The influence of management (i.e. fertilisation and harvest) and environmental driver variables (e.g. soil meteorological variables, soil chemical variables) on $\mathrm{N}_{2} \mathrm{O}$ emissions was investigated based on daily averages of measured $10 \mathrm{~min}$ flux data and the corresponding environmental variables. For introducing management influence in the regression analysis, dates were labelled according to three a priori selected management categories only: postfertilisation $(\mathrm{F})$, post-harvest $(\mathrm{H})$, and no management (here defined as no management during the previous week) (0) in combination with the treatment clover $(\mathrm{Clo})$ or control $(\mathrm{Ctr})$. Thus, five management categories existed (Ctr-F, Ctr-H, Ctr0, Clo-H, Clo-0). The control parcel without recent management activity (Ctr-0) served as the reference level in comparison to all other management categories. As grazing inten- sity is low at the site and grazing did not show any influence on $\mathrm{N}_{2} \mathrm{O}$ exchange, we did not include grazing in the GAM analysis. The full set of predictors included soil temperature, soil water content, oxygen concentration, $\mathrm{NH}_{4}^{-}, \mathrm{NO}_{3}^{+}$and DOC concentration for substrate availability, net ecosystem exchange (NEE) of $\mathrm{CO}_{2}$ as a proxy for plant activity, and the categorical variable for management activity.

All predictors were included as non-linear terms in the first step, and the basic GAM was fitted using generalised crossvalidation as the criterion for the parameter choice resulting in the best fit. This method resulted in several terms being included in the GAM as linear predictors (empirical degrees of freedom, edf $=1$ ). These were finally treated as linear terms in order to obtain their effect sizes. For linear predictors such as soil temperatures, effect sizes can be interpreted as in linear regression models. Soil water content and oxygen concentration showed a non-linear influence on $\log \mathrm{N}_{2} \mathrm{O}$ emissions (reverse $U$ shape), as estimated by the GAM to require more degrees of freedom (edf $>1$ ). These were kept as (nonlinear) smooth terms in the GAM. Stepwise backward elimination was applied for model selection, whereby the number of predictors was reduced until the local minimum value of the Akaike information criterion (AIC) was found. Residual analysis showed that the final model residuals were in line with the assumptions of a Gaussian distributed, homoscedastic error term with a mean of zero.

Due to focusing the analysis on in situ measured data only, models that included the soil sampling variables are limited to the observational days on which manually sampled data 


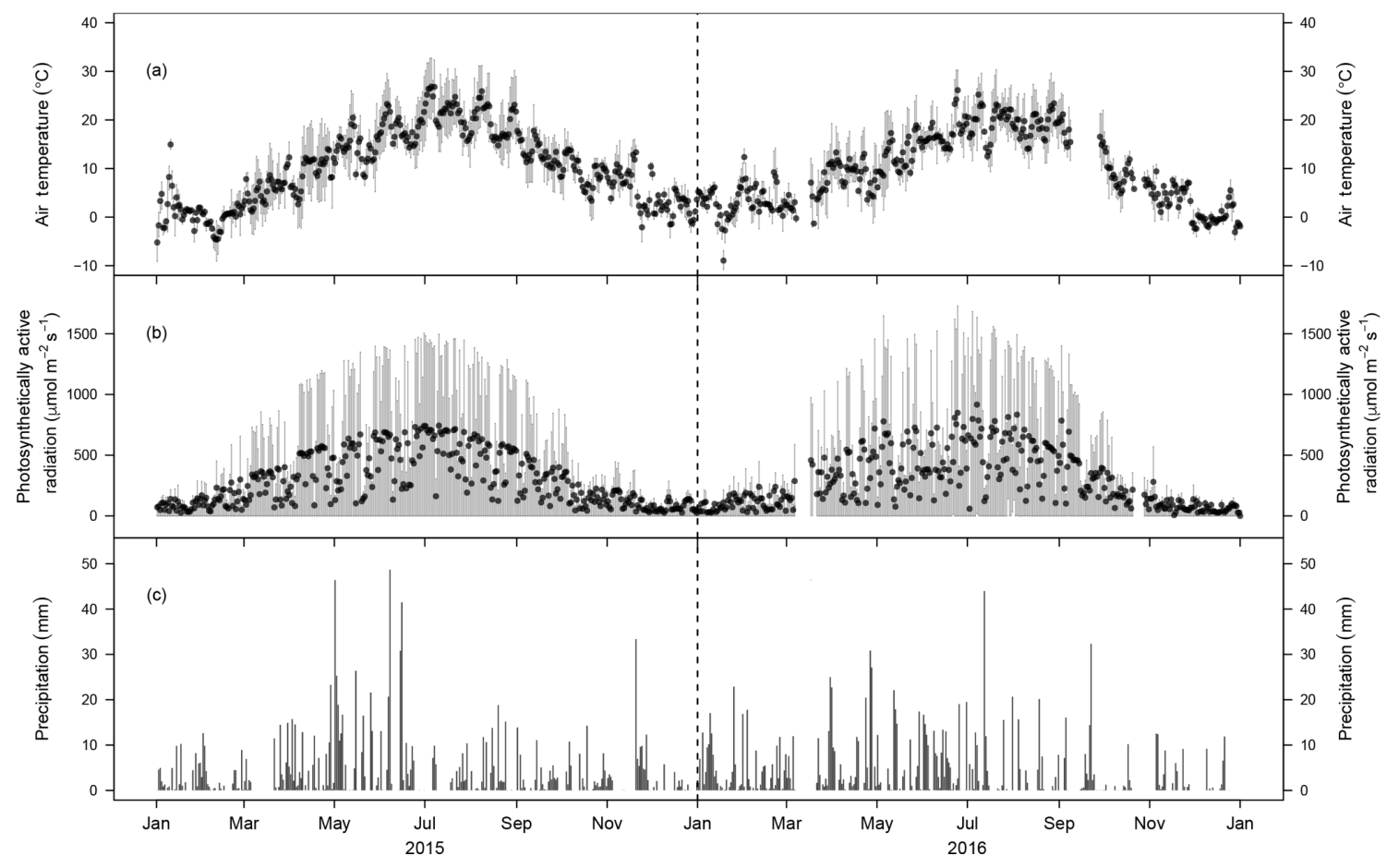

Figure 2. Meteorological conditions during 2015 and 2016. (a) Average daily air temperature (2 m) and (b) average daily photosynthetically active radiation $(2 \mathrm{~m})$. The grey bars indicate the sub-daily variability (quartiles based on 10 min values). (c) Daily precipitation sums during 2015 and $2016(1 \mathrm{~m})$.

were available (full model and optimised model). To check the consistency of these results (i.e. effect sizes) with results from a wider range of observations (year-round continuous measurements) we built a model ("simple model") based on only the major driver variables soil temperatures, SWC, and management as predictors, with the advantage of including more observations due to the wide coverage of these variables. Negative $\mathrm{N}_{2} \mathrm{O}$ fluxes were analysed separately, but no significant effects of the same set of predictors on $\mathrm{N}_{2} \mathrm{O}$ uptake were found. For autocorrelated time series (i.e. soil microclimatic variables) the $t$ test on the differences was corrected for autocorrelation by calculating the effective sample sizes according to Wilks (2011:147) and using the effective sample sizes in the tests, resulting in adjusted standard errors and $p$ values $\left(\mathrm{se}_{\mathrm{adj}} ; p_{\mathrm{adj}}\right)$. All statistical analyses were performed with the open source software R (R Core Team, 2016) using the "mgcv" package (Wood, 2011) for generalised additive modelling.

\section{Results}

\subsection{General environmental conditions}

Mean annual temperatures in 2015 and 2016 were 10.3 and $9.7^{\circ} \mathrm{C}$, respectively (Fig. 2a). Thereby 2015 was $0.2^{\circ} \mathrm{C}$ warmer and 2016 was $0.4^{\circ} \mathrm{C}$ colder than the previous 5 years, which averaged $10.1^{\circ} \mathrm{C}$. Daily photosynthetically active radiation (PAR) followed the typical seasonal pattern (Fig. 2b). Annual precipitation was $1029 \mathrm{~mm}$ in 2015 and $1202 \mathrm{~mm}$ in 2016, which is $7 \%$ lower and $9 \%$ higher, respectively (Fig. 2c), than the 5-year mean annual precipitation $(1101 \mathrm{~mm})$. While both years were characterised by a typical wet beginning of the growing season (MAM with $376 \mathrm{~mm}$ in 2015 and $379 \mathrm{~mm}$ in 2016) similar to the 5 years prior to our period of analysis, the peak growing season (JJA) in 2015 was considerably drier ( $260 \mathrm{~mm}$ of precipitation) than in 2016 (396 mm; Fig. 2c). The growing season, defined by $T_{\text {air }}$ exceeding $5^{\circ} \mathrm{C}$ for at least five subsequent days, started on 17 March 2015 and 30 January 2016. The starting dates of net $\mathrm{CO}_{2}$ uptake for at least 10 subsequent days, an alternative indicator for the start of the growing season, were 27 February 2015 and 8 March 2016, similar to previous years.

\subsection{Soil microclimate}

An important precondition for the $\mathrm{N}_{2} \mathrm{O}$ mitigation experiment is to check for approximately equal soil microclimatic conditions in both parcels, i.e. to exclude the possibility that soil microclimatic variables acted as confounders in the experiment. Soil temperatures were similar in the control (mean $\left.14.5^{\circ} \mathrm{C}\right)$ and the clover parcel $\left(13.6^{\circ} \mathrm{C}\right)$ with measured differences being smaller than the sensor accuracy of $\pm 1^{\circ} \mathrm{C}$. While air temperature fell below $0^{\circ} \mathrm{C}$, soil temperature at $0.1 \mathrm{~m}$ of depth never fell below $0^{\circ} \mathrm{C}$ during the course of the 


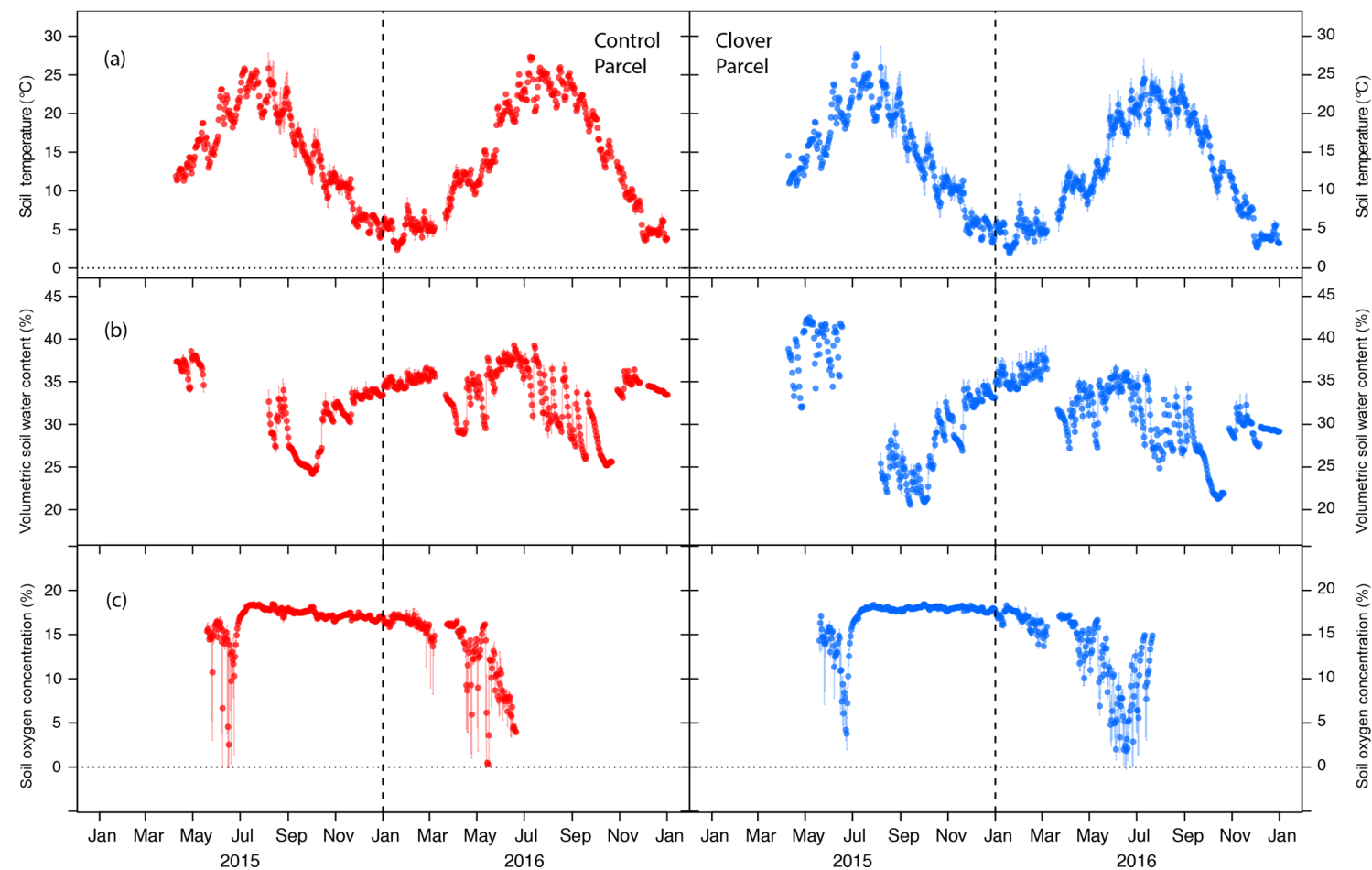

Figure 3. Soil meteorological conditions during 2015 and 2016. (a) Average daily soil temperature (0.1 m of depth), (b) average daily soil water content $(0.1 \mathrm{~m}$ of depth), and (c) average daily soil oxygen concentration $(0.1 \mathrm{~m}$ of depth) at the control (left, red) and clover parcel (right, blue). The bars indicate the sub-daily variability (ranges of $10 \mathrm{~min}$ values).

experiment (Fig. 3a). This was also the case for the two reference years 2013 and 2014. Volumetric soil water content (at $0.1 \mathrm{~m}$ of depth) were similar in the control $(33 \pm 4 \%)$ and the clover parcel $(31 \pm 5 \%)$. The difference between treatments was within the sensor accuracy of $\pm 3 \%$ (Fig. 3b). Oxygen concentration (at $0.1 \mathrm{~m}$ of depth) ranged between $15 \%$ and $21 \%$ during three-quarters of the measurement period and decreased consistently to $0 \%$ during spring in both years (Fig. 3c). Moreover, temporal patterns seen in $\mathrm{O}_{2}$ concentration were not significantly different in both parcels (measured difference $\left.0.3 \pm 0.2 \% \mathrm{se}_{\mathrm{adj}} ; p_{\mathrm{adj}}=0.075\right)$. Oxygen concentration during summer (JJA) 2015 was higher compared to $2016\left(t=2.64 ; p_{\text {adj }}=0.03\right)$ as a consequence of less rainfall compared to summer 2016 (Fig. 2c). Soil oxygen concentration was inversely related to soil water content.

\subsection{Soil mineral $\mathrm{N}$ and DOC concentration}

The ammonium $\left(\mathrm{NH}_{4}^{+}\right)$concentration in the soil peaked on each day of slurry application in the control parcel and declined during the following few days (Fig. 4a). The $\mathrm{NH}_{4}^{+}$$\mathrm{N}$ concentration measured in the topsoil ranged between 0.4 and $19.2 \mathrm{mg} \mathrm{NH}_{4}^{+}-\mathrm{N} \mathrm{kg}^{-1}$ dry soil in the control parcel during the 2 years of observations. A significantly lower $\mathrm{NH}_{4}^{+}$$\mathrm{N}$ concentration was measured in the clover parcel (0.6$11.1 \mathrm{mg} \mathrm{NH}_{4}^{+}-\mathrm{N} \mathrm{kg}^{-1}$ dry soil; paired Wilcoxon test, $p<$ 0.01 ). While the $\mathrm{NH}_{4}^{+}-\mathrm{N}$ concentration peaked after fertilisa- tion events in the control parcel, no consistent patterns were observed in the clover parcel to which no fertiliser was applied. The soil nitrate $\left(\mathrm{NO}_{3}^{-}\right)$concentration ranged between 1.7 and $27.7 \mathrm{mg} \mathrm{NO}_{3}^{-}-\mathrm{N} \mathrm{kg}^{-1}$ dry soil in the control parcel (Fig. 4b). Similar to the observations found for $\mathrm{NH}_{4}^{+}$$\mathrm{N}$, significantly lower soil nitrate levels $\left(0.6-18.9 \mathrm{mg} \mathrm{NO}_{3}^{-}\right.$$\mathrm{N} \mathrm{kg}^{-1}$ dry soil) were found in the clover parcel (paired Wilcoxon test, $p<0.01$ ). The $\mathrm{NO}_{3}^{-}-\mathrm{N}$ concentration significantly increased over the course of the season in the control parcel (Mann-Kendall test, 2015: $\tau=0.50, p<0.001$; 2016: $\tau=0.40, p<0.001)$. Such a trend was not observed in the clover parcel in 2015, while it was significant in 2016 (Mann-Kendall test, 2015: $\tau=0.15, p>0.05 ; 2016: \tau=$ $0.35, p<0.01$ ) (Fig. 4b). Dissolved organic carbon (DOC) measured regularly from soil samples resulted in a range of $42-234 \mathrm{mg} \mathrm{C} \mathrm{kg}^{-1}$ dry soil in the control parcel (Fig. 4c). Again, significantly lower values were measured for DOC in the clover parcel $\left(0.6-160 \mathrm{mg} \mathrm{C} \mathrm{kg}^{-1}\right.$ dry soil) (paired Wilcoxon test, $p<0.01$ ) compared to the control. As observed for $\mathrm{NO}_{3}^{-}-\mathrm{N}$, the DOC concentration significantly increased with the growing season in the control parcel in both years and in the clover parcel in 2016 (Mann-Kendall test, control parcel, 2015: $\tau=0.25, p<0.01 ; 2016: \tau=0.23$, $p<0.05$; clover parcel, 2015: $\tau=0.14, p>0.5$; 2016: $\tau=$ $0.26, p<0.05$ ) (Fig. 4b, c). Overall, soil mineral N and DOC concentrations were lower in the clover parcel. 


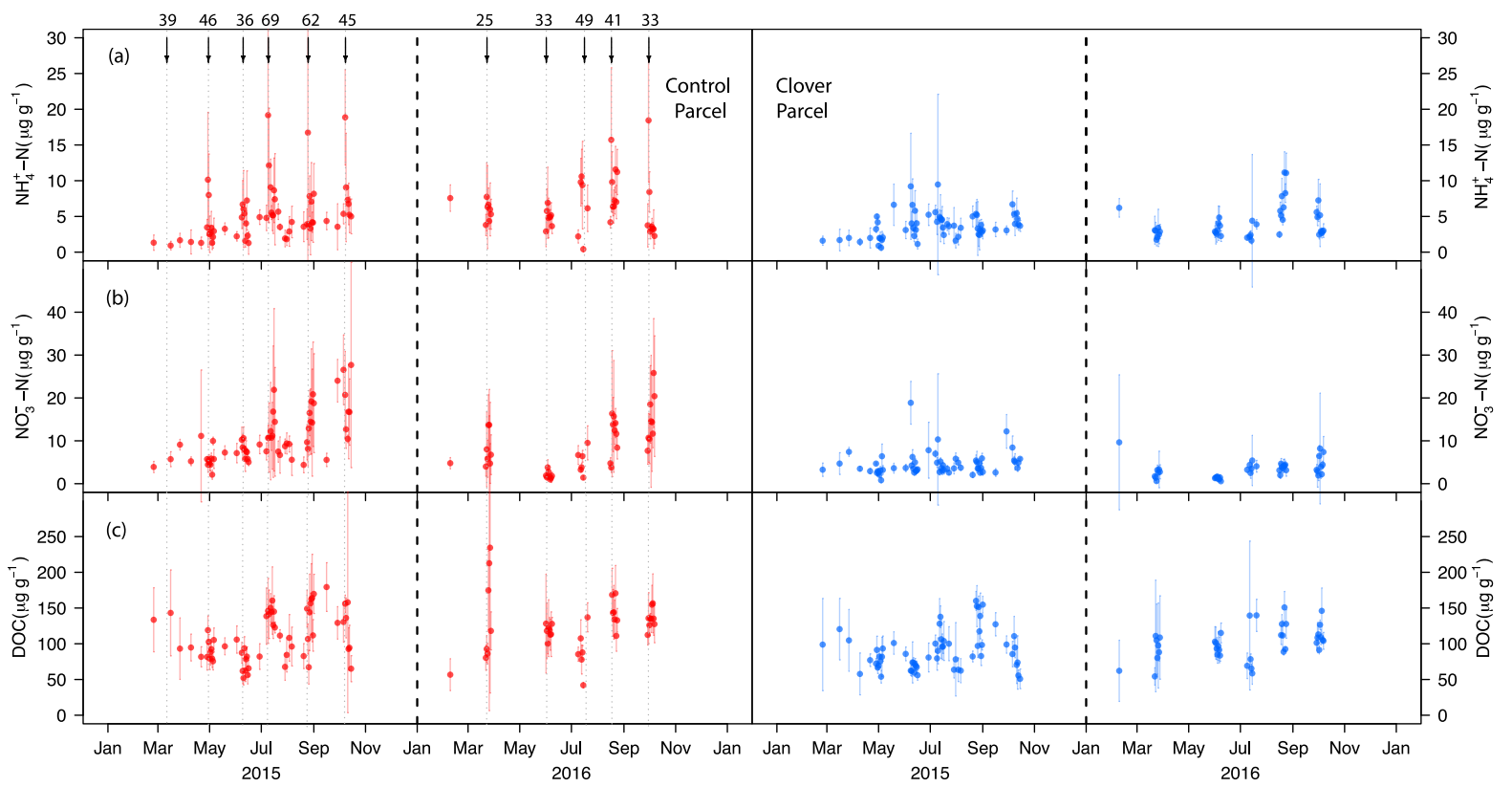

Figure 4. (a) Ammonium-N concentration, (b) nitrate-N concentration, and (c) dissolved organic carbon concentration per unit of dry soil at the control (left, red) and clover parcel (right, blue) during 2015 and 2016. Black arrows indicate slurry applications, which only took place in the control parcel. The numbers above the arrows indicate the amount of $\mathrm{N}\left(\mathrm{kg} \mathrm{ha}^{-1}\right)$ added to the parcel.

\subsection{Sward productivity and vegetation composition}

Total annual yields (mean \pm SE) in the control parcel were $12.8 \pm 0.5 \mathrm{t}$ dry matter $(\mathrm{DM}) \mathrm{ha}^{-1}$ in 2015 and $11.9 \pm$ $0.4 \mathrm{tDMha}^{-1}$ in 2016 , while yields in the clover parcel were $10.4 \pm 0.7$ and $11.0 \pm 0.5 \mathrm{tDM} \mathrm{ha}^{-1}$ in 2015 and 2016, respectively (Table 2). Previous years' yields for both parcels were $9.3 \pm 3.2 \mathrm{tDM} \mathrm{ha}^{-1} \mathrm{yr}^{-1}$ in the control and $6.6 \pm 2.3 \mathrm{tha}^{-1} \mathrm{yr}^{-1}$ in the parcel, which was transformed into the experimental parcel during the years 2015 and 2016 based on data of all years with complete records between 2007 and 2013 (mean difference between parcels 2007-2013 of $-2.7 \mathrm{tha}^{-1} \mathrm{yr}^{-1}$; experiment difference 2015-2016-2.4 and $-0.9 \mathrm{tha}^{-1}$; Table S2). Thus, yield differences between the two parcels in 2015 and 2016 were in the range of yield differences observed during previous years, with yields being $19 \%$ (2015) and $9 \%$ (2016) lower at the clover parcel compared to the control parcel (Fig. 5a). The living aboveground biomass remaining on the parcel after mowing was $1.0 \pm$ $0.3 \mathrm{tDM} \mathrm{ha}^{-1}$ on the control parcel and $0.8 \pm 0.4 \mathrm{tDM} \mathrm{ha}^{-1}$ on the clover parcel (measured on 21 April 2015; Fig. 5b).

The average clover proportion in harvested biomass in 2015 was $14.5 \%$ in the control parcel and $21.4 \%$ in the clover parcel. The difference in clover proportion between the two parcels was more visible in 2016, with $4.1 \%$ clover proportion in the control parcel and $44.2 \%$ in the clover parcel. When analysing individual sampling dates, differences in clover proportion between the control and clover parcel were highly variable in 2015 , with substantially higher values for the clover parcel in the months April and June and slightly lower clover proportion in August compared to the control parcel. In 2016, clover proportions increased and stabilised in the clover parcel, while they decreased in the control parcel with the progress of the growing season (Fig. 5c). Leaf area index (LAI) ranged between 0.4 and 5.9, with a maximum at the first harvest each year (Fig. 5d). Average C concentrations in the biomass of all harvests were similar across parcels and plant functional types (legumes $42.9 \%-45.6 \%$, non-legumes $43.0 \%-45.2 \% \mathrm{C}$ in biomass across parcels and years; Table 2, Fig. 5e). Average $\mathrm{N}$ concentrations in the biomass were always higher in legumes $(3.3 \pm 0.2 \%)$ compared to non-legumes $(2.1 \pm 0.2 \%)$ (Fig. $5 f)$. The $\mathrm{C} / \mathrm{N}$ ratios (data not shown) of total annual yields were slightly higher in the control $(19.2 \pm 1.7$ and $19.8 \pm 2.8)$ than in the clover parcel $(17.1 \pm 1.0$ and $16.7 \pm 2.1)$ for both years. Vegetation height reflected the vegetation dynamics and reached similar maxima on the control parcel $(41$ and $59 \mathrm{~cm})$ and the clover parcel $(44$ and $60 \mathrm{~cm}$ ) in 2015 and 2016 (Fig. 5g). C in annual yields at the control parcel was higher $\left(5.8 \pm 0.2 \mathrm{tha}^{-1}\right) \mathrm{com}$ pared to the clover parcel $\left(4.7 \pm 0.3 \mathrm{tha}^{-1}\right)$ in 2015 , while C in biomass was similar for the control parcel $\left(5.1 \pm 0.3 \mathrm{tha}^{-1}\right)$ and the clover parcel $\left(4.8 \pm 0.2 \mathrm{tha}^{-1} \mathrm{yr}^{-1}\right)$ in 2016 (Table 2). The $\mathrm{N}$ exported was similar across parcels in the second year (control: $238 \pm 13 \mathrm{~kg} \mathrm{ha}^{-1} \mathrm{yr}^{-1}$; clover: $262 \pm 8 \mathrm{~kg} \mathrm{ha}^{-1} \mathrm{yr}^{-1}$; Table 2). Biological nitrogen fixation via rhizobia associated with clover ( $\mathrm{N}$ derived from the atmosphere $-\mathrm{N}_{\mathrm{dfa}}$ ) resulted in BFN in harvested biomass of $55.6 \pm 5.3 \mathrm{~kg} \mathrm{~N} \mathrm{ha}^{-1} \mathrm{yr}^{-1}$ and $14.2 \pm 1.7 \mathrm{~kg} \mathrm{~N} \mathrm{ha}^{-1} \mathrm{yr}^{-1}$ in the control parcel and $71.6 \pm$ 


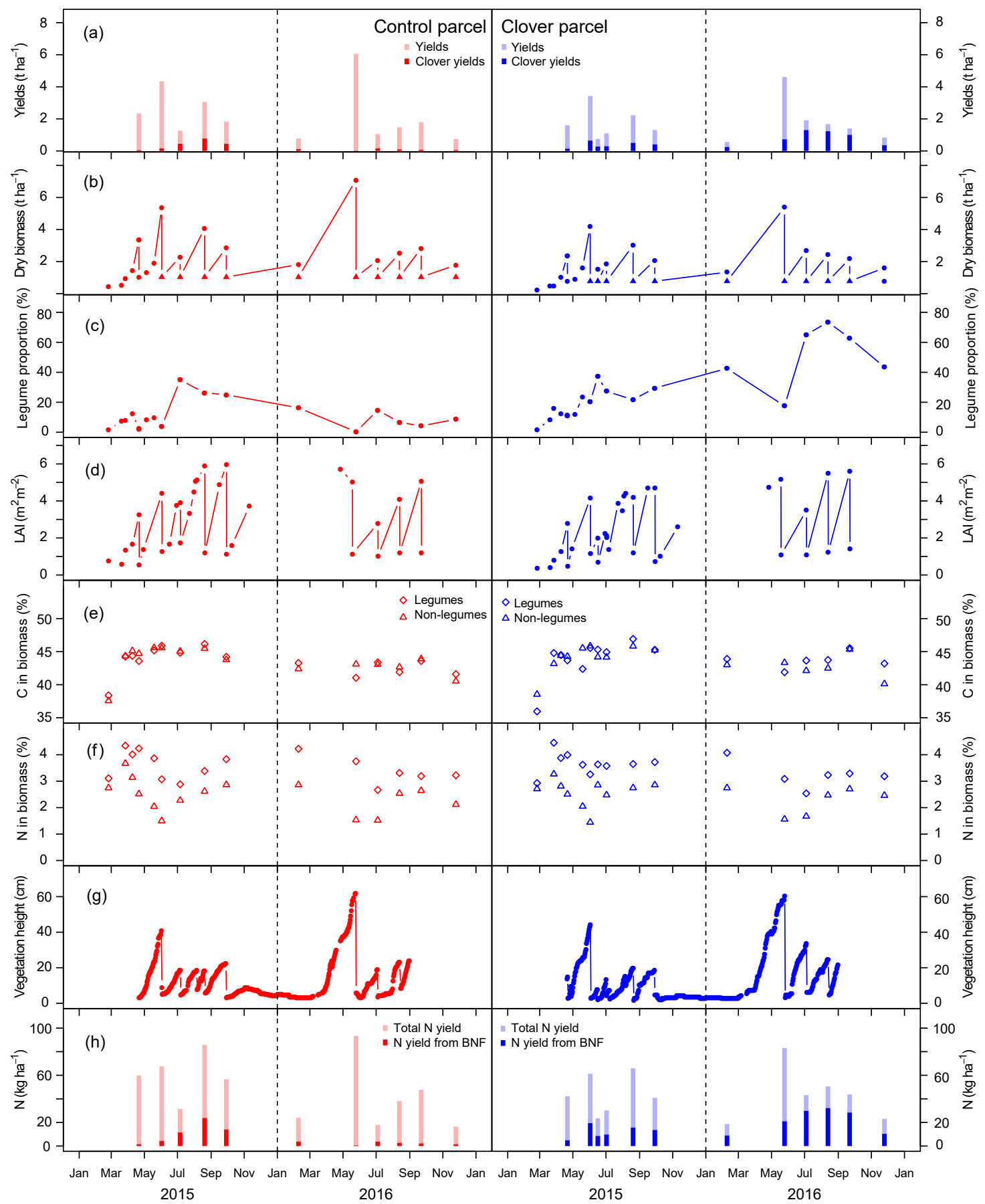

Figure 5. (a) Yields and intake by grazing at the control (left, red) and clover parcel (right, blue); (b) total aboveground biomass. Circles represent the total biomass (legumes and non-legumes), and filled triangles display the remaining biomass after harvest (stubble), which was measured once (sampling date 21 April 2015) and assumed to be approximately similar during subsequent harvests. (c) Clover proportion in dry biomass, (d) leaf area index (LAI), (e) C content, and (f) $\mathrm{N}$ content in biomass. Diamonds represent the legumes and triangles nonlegumes. (g) Vegetation heights derived from webcam images; (h) amounts of total $\mathrm{N}$ removal at harvest (semi-transparent), including total amount of BFN in the removed biomass (saturated). 

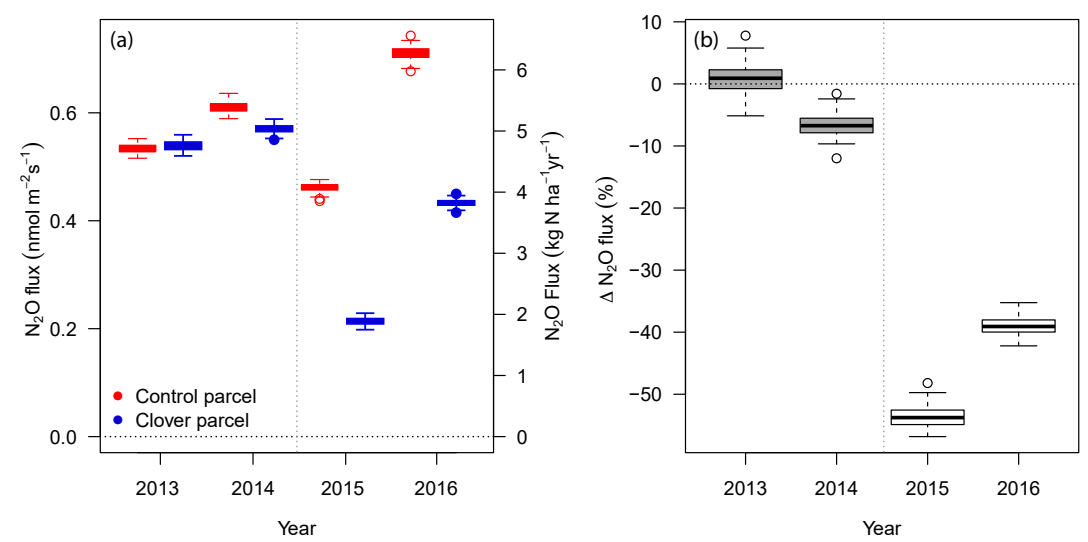

Figure 6. (a) Annual $\mathrm{N}_{2} \mathrm{O}$ exchange at the control (red) and clover parcels (blue) for the reference years 2013-2014 and the experimental years 2015-2016. (b) Relative differences between $\mathrm{N}_{2} \mathrm{O}$ exchange in the control and clover parcels for the reference years (grey) and the experimental years (white). Boxes indicate the interquartile range based on non-parametric bootstrapping; bold black lines within boxes indicate the medians.

5.0 and $130 \pm 8.0 \mathrm{~kg} \mathrm{Nha}^{-1} \mathrm{yr}^{-1}$ in the clover parcel during the first and the second year of the experiment, respectively (Table 2, Fig. 5h).

\subsection{Differences in $\mathrm{N}_{2} \mathrm{O}$ exchange between control and clover parcel}

Average $\mathrm{N}_{2} \mathrm{O}$ fluxes (with $95 \%$ confidence interval, CI, from the bootstrapping given in parentheses) in the control parcel in 2015 were $4.1 \mathrm{~kg} \mathrm{~N}_{2} \mathrm{O}-\mathrm{N} \mathrm{ha}^{-1} \mathrm{yr}^{-1}$ (CI3.8$4.2 \mathrm{~kg} \mathrm{~N}_{2} \mathrm{O}-\mathrm{Nha}^{-1} \mathrm{yr}^{-1}$ ) and $1.9 \mathrm{~kg} \mathrm{~N}_{2} \mathrm{O}-\mathrm{N} \mathrm{ha}^{-1} \mathrm{yr}^{-1}$ (CI 1.8-2.0 $\mathrm{kg} \mathrm{N}_{2} \mathrm{O}-\mathrm{N} \mathrm{ha}^{-1} \mathrm{yr}^{-1}$ ) in the clover parcel. In 2016, average $\mathrm{N}_{2} \mathrm{O}$ fluxes were higher for both parcels (6.3 $\mathrm{kg} \mathrm{N}_{2} \mathrm{O}-\mathrm{N} \mathrm{ha}^{-1} \mathrm{yr}^{-1}$, CI 6.0-6.5 $\mathrm{kg} \mathrm{N}_{2} \mathrm{O}-\mathrm{N} \mathrm{ha}^{-1} \mathrm{yr}^{-1}$ in the control and $3.8 \mathrm{~kg} \mathrm{~N}_{2} \mathrm{O}-\mathrm{N} \mathrm{ha}^{-1} \mathrm{yr}^{-1}$, CI $3.7-3.9 \mathrm{~kg} \mathrm{~N}_{2} \mathrm{O}$ $\mathrm{Nha}^{-1} \mathrm{yr}^{-1}$ in the clover parcel) (Fig. 6a). Annual $\mathrm{N}_{2} \mathrm{O}$ fluxes in the clover parcel were $54 \%(51 \%-57 \%$ as $95 \%$ confidence intervals) and $39 \%(36 \%-42 \%)$ lower than at the control parcel in 2015 and 2016, respectively (Fig. 6b). During the reference year 2013, average $\mathrm{N}_{2} \mathrm{O}$ fluxes in the control parcel were $4.7 \mathrm{~kg} \mathrm{~N}_{2} \mathrm{O}-\mathrm{N} \mathrm{ha}^{-1} \mathrm{yr}^{-1}$ (4.6-4.8 $\mathrm{kg} \mathrm{N}_{2} \mathrm{O}-\mathrm{Nha}^{-1} \mathrm{yr}^{-1}$ ) and in the clover parcel $4.8 \mathrm{~kg} \mathrm{~N}_{2} \mathrm{O}-\mathrm{N} \mathrm{ha}^{-1} \mathrm{yr}^{-1}\left(4.6-4.9 \mathrm{~kg} \mathrm{~N}_{2} \mathrm{O}-\mathrm{N} \mathrm{ha}^{-1} \mathrm{yr}^{-1}\right)$ and thus did not differ significantly. $\mathrm{N}_{2} \mathrm{O}$ emission intensities (yield-scaled $\mathrm{N}_{2} \mathrm{O}$ emissions) during the experiment were $0.31 \mathrm{~g} \mathrm{~N}_{2} \mathrm{O}-\mathrm{N} \mathrm{kg}^{-1} \mathrm{DM}$ in the control parcel and thus higher than the $0.18 \mathrm{~g} \mathrm{~N}_{2} \mathrm{O}-\mathrm{N} \mathrm{kg}^{-1} \mathrm{DM}$ observed in the clover parcel in 2015. A similar pattern was observed in 2016, with $\mathrm{N}_{2} \mathrm{O}$ emission intensities of $0.53 \mathrm{~g} \mathrm{~N}_{2} \mathrm{O}-\mathrm{N} \mathrm{kg}^{-1} \mathrm{DM}$ versus $0.37 \mathrm{~g} \mathrm{~N}_{2} \mathrm{O}-\mathrm{N} \mathrm{kg}^{-1} \mathrm{DM}$ in 2016 for the control and clover parcel, respectively.

\subsection{Effects of management activities on $\mathrm{N}_{2} \mathrm{O}$ exchange}

We observed increased $\mathrm{N}_{2} \mathrm{O}$ fluxes after fertilisation in the control parcel, with maximum daily $\mathrm{N}_{2} \mathrm{O}$ fluxes reaching
$17.4 \mathrm{mg} \mathrm{N}_{2} \mathrm{O}-\mathrm{N} \mathrm{m}^{-2} \mathrm{~d}^{-1}$ on 25 August 2015 (Fig. S1a), a day of slurry amendment. The effect of fertiliser amendment on $\mathrm{N}_{2} \mathrm{O}$ fluxes depended on the environmental conditions during and after the fertilisation event. While several events (e.g. 10 June 2015, 25 August 2015, 16 July 2016, and 17 August 2016; Fig. S1a) were followed by increased $\mathrm{N}_{2} \mathrm{O}$ emissions, other events (e.g. 1 June 2016) did not show such an effect (Fig. S1a; interquartile range displayed in Fig. 7a). $\mathrm{N}_{2} \mathrm{O}$ fluxes decreased to background levels within a few (3-7) days after fertiliser application. Harvest had a moderate influence on $\mathrm{N}_{2} \mathrm{O}$ emissions on both parcels (Fig. 7c). Maximum daily $\mathrm{N}_{2} \mathrm{O}$ fluxes after harvest were $7.0 \mathrm{mg} \mathrm{N}_{2} \mathrm{O}$ $\mathrm{N} \mathrm{m}^{-2} \mathrm{~d}^{-1}$ on 5 July 2016 (Fig. S1a). Average $\mathrm{N}_{2} \mathrm{O}$ fluxes on both parcels were significantly higher the weeks after harvest (average of both parcels: $2.0 \mathrm{mg} \mathrm{N}_{2} \mathrm{O}-\mathrm{N} \mathrm{m}^{-2} \mathrm{~d}^{-1}$ ) compared to average fluxes during the preharvest weeks $\left(1.4 \mathrm{mg} \mathrm{N}_{2} \mathrm{O}\right.$ $\mathrm{N} \mathrm{m}^{-2} \mathrm{~d}^{-1}$ ) (Fig. 7b). Neither grazing nor rain events significantly affected $\mathrm{N}_{2} \mathrm{O}$ exchange (Fig. 7c, d).

\subsection{Influence of potential drivers on $\mathrm{N}_{2} \mathrm{O}$ exchange}

Nitrous oxide emissions significantly increased after fertiliser application ( $\mathrm{Ctr}-\mathrm{F}$ compared to $\mathrm{Ctr}-0, p<0.05)$ compared to $\mathrm{N}_{2} \mathrm{O}$ fluxes during periods of no management on the same (control) parcel (Fig. 8a, Table 4). The effect size showed 2.5-fold $\mathrm{N}_{2} \mathrm{O}$ emissions during the 7 days following slurry amendment compared to no management (resulting from applying the back-transformation to the fertilisation effect: $10^{0.4}=2.5$; Table 4 ). The effects of management influence $\mathrm{N}_{2} \mathrm{O}$ fluxes jointly with other measured driver variables, such as soil moisture, soil temperature, $\mathrm{NH}_{4}^{+}-\mathrm{N}, \mathrm{NO}_{3}^{-}$$\mathrm{N}$, and DOC concentration in the soil. After mowing no significant increase in $\mathrm{N}_{2} \mathrm{O}$ emissions was found for the optimised model in either of the parcels (Table $4 b$ ). In contrast, a difference in $\mathrm{N}_{2} \mathrm{O}$ emissions after harvest was observed for the simple model on the control parcel (Table 4c). If the dif- 


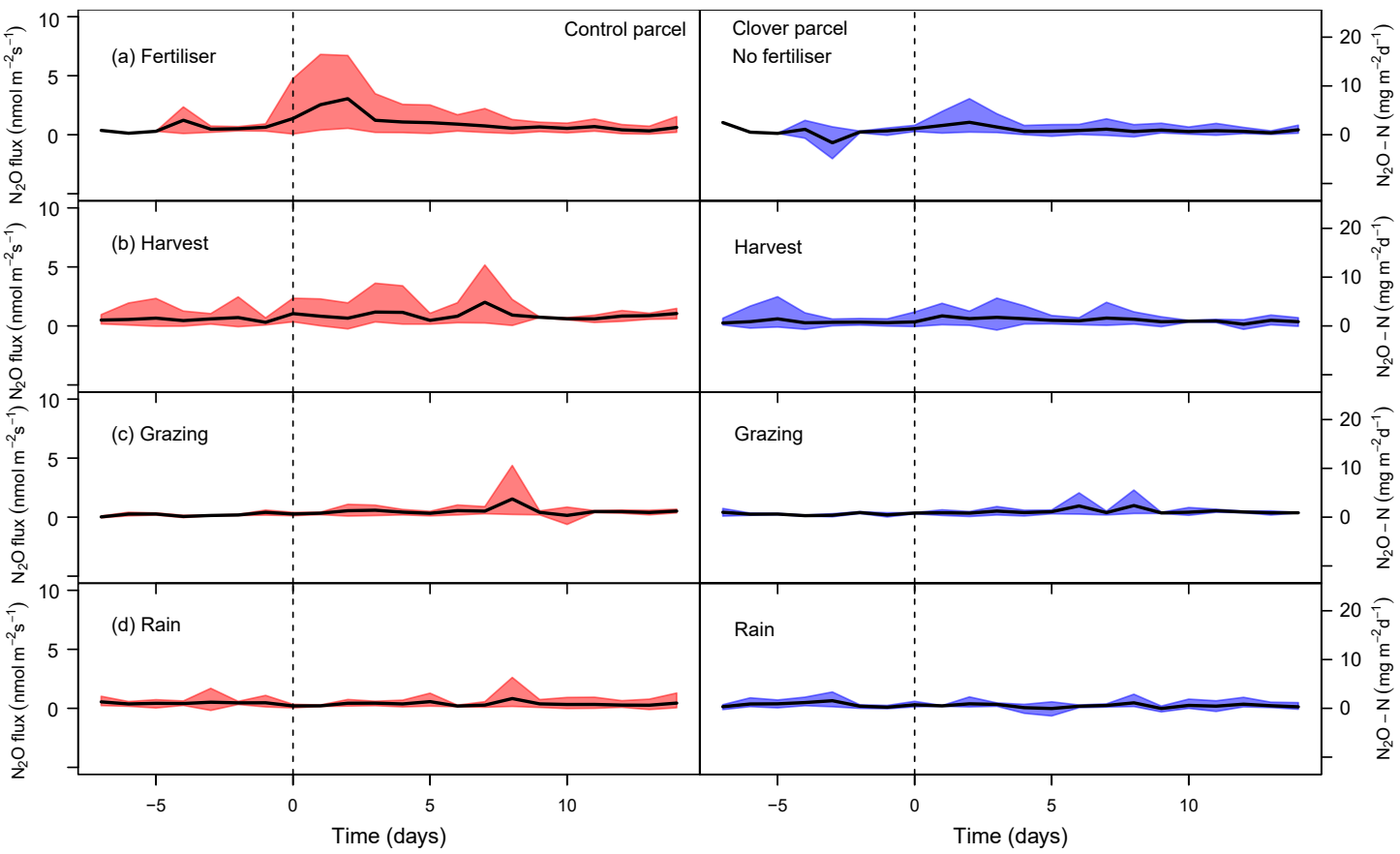

Figure 7. $\mathrm{N}_{2} \mathrm{O}$ fluxes (bold lines: average; colour bands: interquartile range of daily means across all events in 2015 and 2016 ) in the control and the clover parcels from 1 week before to 2 weeks after management events: after (a) organic fertiliser application, (b) harvests, (c) grazing events, and (d) rain events. The black dashed line indicates the start of an event.

ference in sward composition itself affected $\mathrm{N}_{2} \mathrm{O}$ emissions (e.g. via plant residues or rhizodeposition), we expected a significant effect of the clover treatment compared to the control during times without management (Ctr- 0 , which was the reference compared to Clo-0; Table 4). Due to the absence of such an effect, we deduce that the increased clover proportions at the clover parcel did not affect $\mathrm{N}_{2} \mathrm{O}$ emissions.

Soil microclimate affected $\mathrm{N}_{2} \mathrm{O}$ emissions in both parcels. Soil temperature significantly influenced $\mathrm{N}_{2} \mathrm{O}$ emissions $(p<0.05)$, indicating a $7 \%( \pm 2 \%)$ increase in $\mathrm{N}_{2} \mathrm{O}$ per ${ }^{\circ} \mathrm{C}$ temperature increase $(p<0.05$; Table 4 , Fig. 8 b). Soil temperature had the highest explanatory power $\left(r^{2}=0.17\right)$ for the prediction of log-transformed $\mathrm{N}_{2} \mathrm{O}$ flux as a single explanatory variable (data not shown). Besides soil temperature, volumetric soil water content showed a significant non-linear effect on $\mathrm{N}_{2} \mathrm{O}$ emissions ( $p<0.05$; Fig. 8c). The humpback-shaped functional relationship between volumetric soil water content and log-transformed $\mathrm{N}_{2} \mathrm{O}$ emissions (Fig. 8c) shows an increase until $34 \%$ and a decrease above $36 \%$ volumetric soil water content. Similarly, oxygen concentration significantly affected $\mathrm{N}_{2} \mathrm{O}$ emissions ( $p<0.05$; Fig. 8d). Oxygen concentration was non-linearly related to $\mathrm{N}_{2} \mathrm{O}$ emissions, showing the lowest $\mathrm{N}_{2} \mathrm{O}$ emissions $\left(10^{-4} \mu \mathrm{mol} \mathrm{m} \mathrm{m}^{-2} \mathrm{~s}^{-1}\right)$ at $0 \%$ oxygen concentration. $\mathrm{N}_{2} \mathrm{O}$ emissions increased until a maximum was reached at $17 \%-19 \%$ oxygen concentration and then decreased with further increasing oxygen concentration to atmospheric concentrations of $20.9 \%$ (Fig. 8d). The net ecosystem exchange of $\mathrm{CO}_{2}$, which was used here as a proxy for plant activity, affected $\mathrm{N}_{2} \mathrm{O}$ emissions ( $p<0.05$; Fig. 8e) with a $4 \%( \pm 2 \%)$ decrease in $\mathrm{N}_{2} \mathrm{O}$ emissions per $\mu \mathrm{mol} \mathrm{m}^{-2} \mathrm{~s}^{-1}$ net carbon dioxide uptake. Inclusion of $\mathrm{NH}_{4}^{+}-\mathrm{N}$ concentration improved the prediction of $\mathrm{N}_{2} \mathrm{O}$ emissions (Table 4, Fig. 8f), leading to an emission increase of $5 \%( \pm 3 \%)$ per $\mu \mathrm{mol} \mathrm{m}^{-2} \mathrm{~s}^{-1}$. Note that large $\mathrm{NH}_{4}^{+}-\mathrm{N}$ concentrations only occurred after fertilisation, and thus the $\mathrm{NH}_{4}^{+}-\mathrm{N}$ effect was mainly influenced by these dates, while it did not play a role for the other management categories. In contrast, the $\mathrm{NO}_{3}^{-}-\mathrm{N}$ concentration did not improve the prediction of $\mathrm{N}_{2} \mathrm{O}$ emissions (Table 4, Fig. 8g). Also, DOC concentrations showed no effect on $\mathrm{N}_{2} \mathrm{O}$ emissions (Table 4, Fig. 8h). The slopes of the relationship between drivers and predicted $\mathrm{N}_{2} \mathrm{O}$ emission are flatter than expected from visual inspection of the observed values (Fig. 8), as the predictions here depict the dependency of $\mathrm{N}_{2} \mathrm{O}$ emissions on the respective driver alone (based on averages of all other drivers) in contrast to observations, which depict combinations of the effects of several drivers. The effects of soil temperature, soil water content, and management in the full and the optimised model (Table $4 a$ and $b$ ) were consistent with the simple model (Table 4c) that included only these three variables and therefore more observations $(n=891$ versus $n=93)$. Including additional variables $\left(\mathrm{O}_{2}\right.$, $\mathrm{NH}_{4}^{+}-\mathrm{N}, \mathrm{NEE}$ of $\mathrm{CO}_{2}$ ) besides soil temperature and soil water content increased the explained variance in $\mathrm{N}_{2} \mathrm{O}$ emissions from $26.3 \%$ in the simple model (Table $4 \mathrm{c}$ ) to $54.5 \%$ in the optimised model (Table 4b). 
Table 4. Results of generalised additive models (GAMs) (a) including all variables (full model), (b) reduced after stepwise backward elimination, dismissing DOC and nitrate (optimised model), and (c) simplified including only management, soil temperature (TS), and volumetric soil water content (SWC). The control parcel without recent management (Ctr-0) was used as the reference level for the categorical variable management, and thus the constant represents predictions for $\mathrm{Ctr}-0$ and the effect sizes of all other management categories depict differences compared to Ctr- 0 . The effect sizes are displayed with their standard errors and $p$ values for all linear terms. For the non-linear terms soil water content and oxygen concentration, the respective empirical degrees of freedom (edf) and $p$ values are shown. The effect sizes are direct model outputs, while the values used in the text were back-transformed to increase comprehensibility.

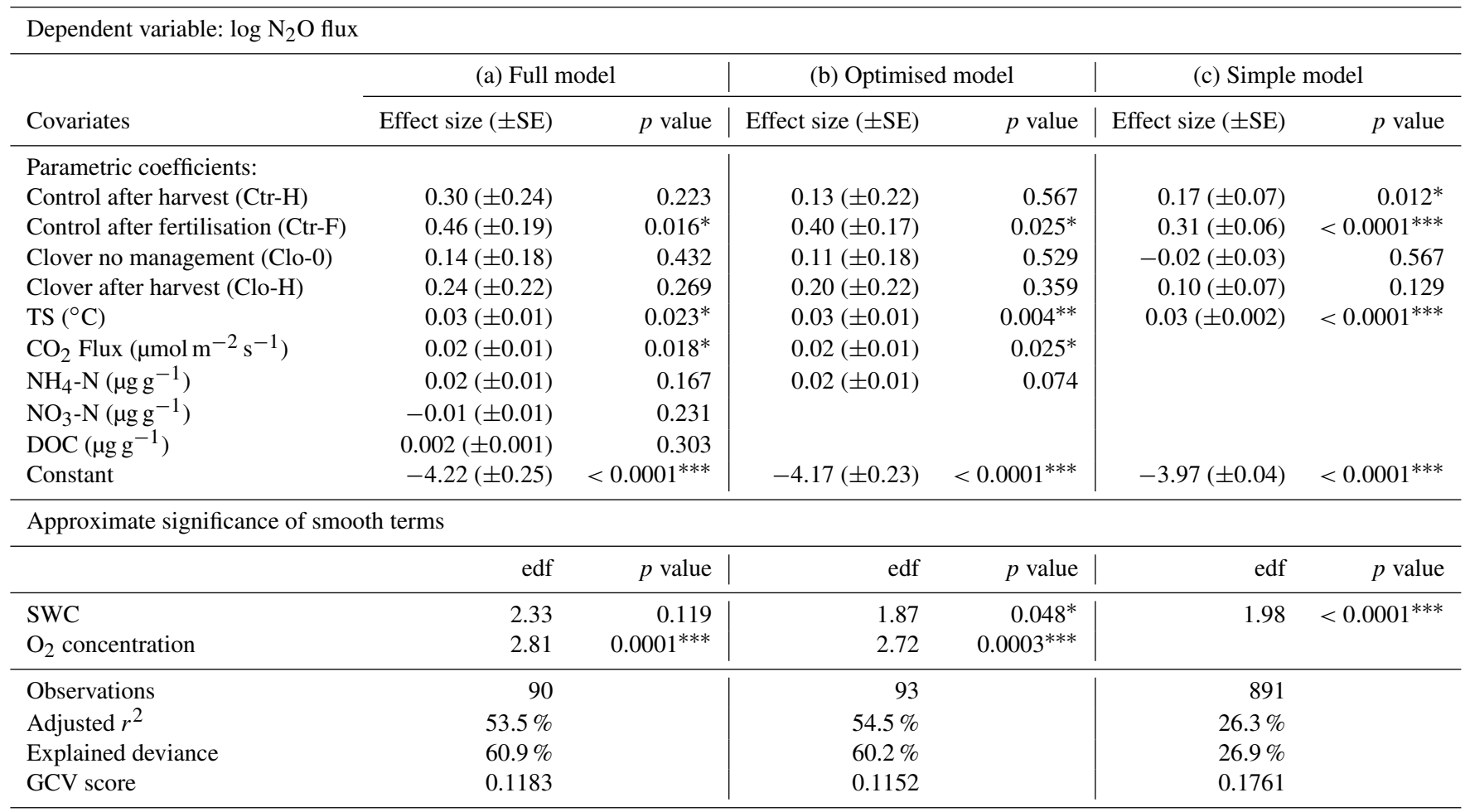

${ }^{*} p<0.05,{ }^{* *} p<0.01,{ }^{* * *} p<0.001$.

\section{Discussion}

We quantified ecosystem $\mathrm{N}_{2} \mathrm{O}$ exchange at a fertilised control parcel ("business as usual") and an unfertilised clover parcel for which we increased the clover proportion ("mitigation management"). The mitigation management was composed of two major changes compared to the "business as usual" practice: (1) omitted fertilisation and (2) over-sowing clover, leading to an increased clover proportion in the experimental sward (i.e. $21 \%$ versus $15 \%$ in $2015,44 \%$ versus $4 \%$ in 2016). Our analysis showed that the difference in $\mathrm{N}_{2} \mathrm{O}$ emissions between the two parcels can be attributed to the absence of fertilisation on the clover parcel. An increased clover proportion could still have increased $\mathrm{N}_{2} \mathrm{O}$ emissions in the clover parcel due to $\mathrm{N}$-rich clover residues and $\mathrm{N}$ from root exudates (Rochette and Janzen, 2005), thereby offsetting the effect of reduced fertilisation. However, we measured similar $\mathrm{N}_{2} \mathrm{O}$ fluxes originating from the two parcels of different clover proportion during periods without management, indicating that differences in clover proportion alone (i.e. excluding recent management effects) resulted in unchanged
$\mathrm{N}_{2} \mathrm{O}$ emissions (i.e. plant residues and root exudates affected $\mathrm{N}_{2} \mathrm{O}$ emissions similarly on the clover and the control parcel). We quantified the effects of environmental drivers on $\mathrm{N}_{2} \mathrm{O}$ emissions and identified soil temperature, soil oxygen concentration, soil water content, and NEE of $\mathrm{CO}_{2}$ as the main environmental drivers of $\mathrm{N}_{2} \mathrm{O}$ emissions. The assessment of the mitigation strategy revealed reductions in $\mathrm{N}_{2} \mathrm{O}$ emissions, an increase in BFN, and stable yields under mitigation management.

This study covered 2 years and did not include potential effects of the incorporation of clover into the soil during ploughing (which takes place every 8-10 years). Long-term effects of the mitigation strategy on the $\mathrm{N}$ budget of the site, as well as implications on the farm level (e.g. the feasibility to use the slurry to replace mineral fertiliser elsewhere, fodder composition), should be investigated in future studies. In summary, our results indicate that $\mathrm{N}_{2} \mathrm{O}$ emissions can be effectively reduced at ecosystem scale through enhancing the clover proportion (and BFN) in permanent grassland while reducing organic fertiliser inputs and still meeting the $\mathrm{N}$ requirements of plants. 

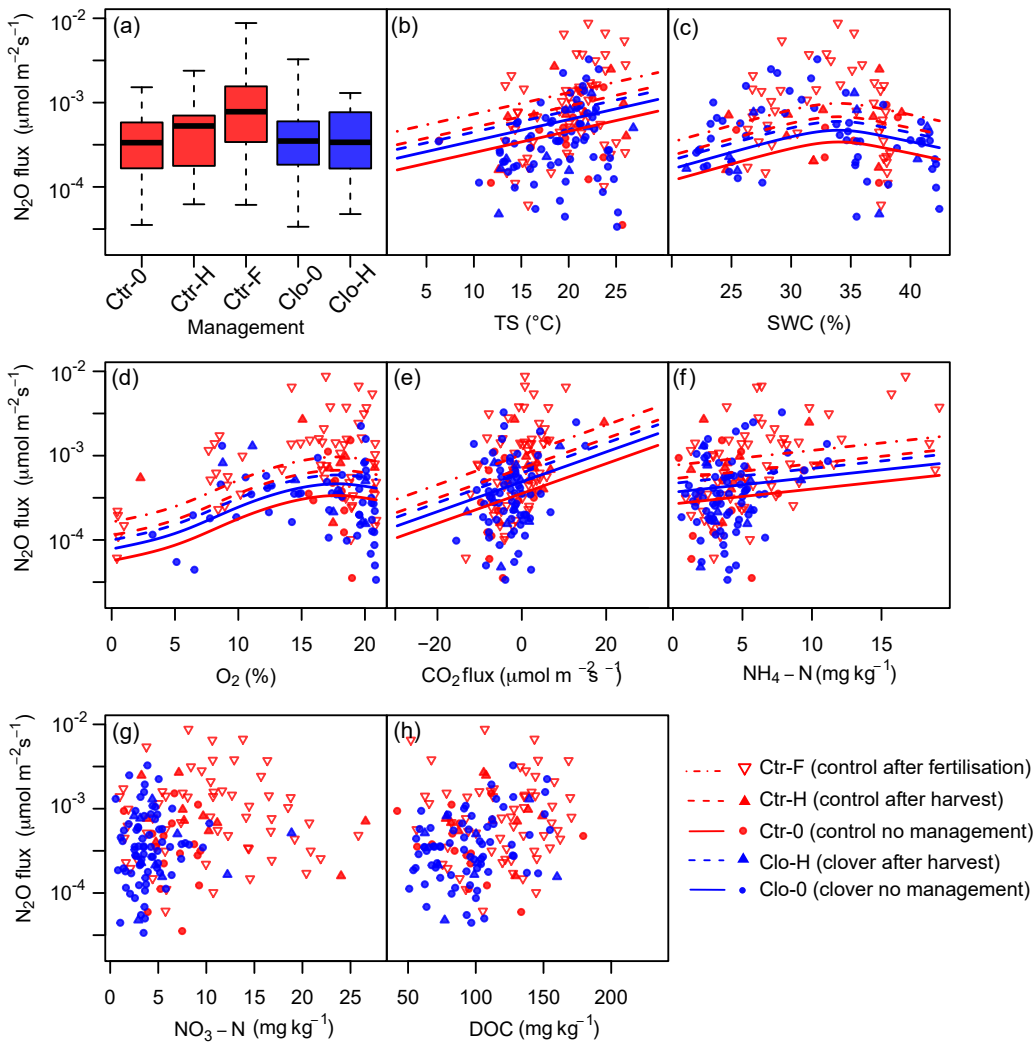

Figure 8. Influence of management and environmental variables on $\mathrm{N}_{2} \mathrm{O}$ emissions as predicted by the generalised additive model (GAM). Significant effects were found for (a) management, (b) soil temperature (TS, $0.1 \mathrm{~m}$ of depth), (c) soil water content (SWC, $0.1 \mathrm{~m}$ of depth), (d) oxygen concentration $\left(\mathrm{O}_{2}, 0.1 \mathrm{~m}\right.$ of depth), and (e) carbon dioxide $\left(\mathrm{CO}_{2}\right)$ flux; while not significant, (f) ammonium-N concentration $\left(\mathrm{NH}_{4}-\mathrm{N}, 0-0.2 \mathrm{~m}\right.$ of depth) still improved the model (lowered the AIC). No significant influence was found for (g) nitrate-N concentration $\left(\mathrm{NO}_{3}-\mathrm{N}, 0-0.2 \mathrm{~m}\right.$ of depth) and (h) dissolved organic carbon concentration (DOC, $0-0.2 \mathrm{~m}$ of depth). Measurements are displayed as squares for "no management", with upward triangles for harvests at the control (red) and clover (blue) parcels and downward triangles (red) for fertilisation (control). Predictions are displayed if lowering AIC as solid lines for the category "no management", as dashed lines for harvests, and as dot-dashed lines for fertilisation based on average values for all other drivers.

\section{1 $\mathrm{N}_{2} \mathrm{O}$ emissions in the fertilised grassland parcel}

$\mathrm{N}_{2} \mathrm{O}$ emissions in the control parcel totaled 4.1 and $6.3 \mathrm{~kg} \mathrm{~N}_{2} \mathrm{O}-\mathrm{N} \mathrm{ha}^{-1} \mathrm{yr}^{-1}$ for the 2 years, respectively, corresponding to $1.4 \%$ and $3.5 \%$ of the applied fertiliser $\mathrm{N}$. Annual $\mathrm{N}_{2} \mathrm{O}$ emissions are of the same order of magnitude as the values reported from the site in previous years (2010 and 2011) by Imer et al. (2013), who estimated 2.2$7.4 \mathrm{~kg} \mathrm{~N}_{2} \mathrm{O}-\mathrm{N} \mathrm{ha}^{-1} \mathrm{yr}^{-1}$ based on manual $\mathrm{N}_{2} \mathrm{O}$ measurements using static $\mathrm{GHG}$ chambers. Similar $\mathrm{N}_{2} \mathrm{O}$ emissions of $4.5 \mathrm{~kg} \mathrm{~N}_{2} \mathrm{O}-\mathrm{N} \mathrm{ha}^{-1} \mathrm{yr}^{-1}\left(0.3-18.2 \mathrm{~kg} \mathrm{~N}_{2} \mathrm{O}-\mathrm{N} \mathrm{ha}^{-1} \mathrm{yr}^{-1}\right)$ from other fertilised grassland sites were reported by Jensen et al. (2012) in a synthesis paper covering 19 site years. Fertilised grassland sites in central Europe, particularly grasslands at higher altitudes, typically gave lower $\mathrm{N}_{2} \mathrm{O}$ emissions $\left(0.19-5.28 \mathrm{~kg} \mathrm{~N}_{2} \mathrm{O}-\mathrm{N} \mathrm{ha}^{-1} \mathrm{yr}^{-1}\right.$ across site years, or $0.1 \%-2.5 \%$ of fertiliser input) compared to our site, which showed the highest emissions with respect to both absolute
$\mathrm{N}_{2} \mathrm{O}$ emissions and emissions as a percentage of fertiliser $\mathrm{N}$ input $\left(2.55-7.89 \mathrm{~kg} \mathrm{~N}_{2} \mathrm{O}-\mathrm{N} \mathrm{ha}^{-1} \mathrm{yr}^{-1}\right.$ or $1.1 \%-3.6 \%$ of fertiliser $\mathrm{N}$ input across site years 2010-2013) as reported by Hörtnagl et al. (2018) compared to $1.4 \%-3.5 \%$ of fertiliser $\mathrm{N}$ in our study (2015 and 2016). For a more targeted comparison, here we considered only the non-restoration site years and excluded 2012, which showed high $\mathrm{N}_{2} \mathrm{O}$ emissions particularly related to grassland restoration. The Hörtnagl et al. (2018) study covered the years 2010-2013 for our site but used a different gap-filling method. The high emissions from our site were explained by warm temperatures $\left(\sim 20^{\circ} \mathrm{C}\right)$, combined with moist to wet soil moisture conditions after fertiliser events, and therefore particularly favourable conditions for $\mathrm{N}_{2} \mathrm{O}$ production compared to conditions at other sites. Hörtnagl et al. (2018) used a conservative method to estimate fluxes during periods without measurement (running median gap filling, resulting in low estimates when gaps are filled during emission peaks). In this study, gaps 
Table 5. Summary of studies investigating $\mathrm{N}_{2} \mathrm{O}$ emissions simultaneously in permanent grasslands of at least two different clover proportions. We included studies with $>200$ days of temporal coverage and at least biweekly sampling of $\mathrm{N}_{2} \mathrm{O}$ emissions or, if discontinuously sampled, included a sensible strategy used by the authors in order to estimate annual fluxes.

\begin{tabular}{|c|c|c|c|c|}
\hline Source & Treatment & $\begin{array}{r}N_{\text {fert }} \\
\left(\mathrm{kg} \mathrm{Nha}^{-1} \mathrm{yr}^{-1}\right)\end{array}$ & $\begin{array}{r}\text { Clover } \\
\%\end{array}$ & $\begin{array}{r}\mathrm{N}_{2} \mathrm{O} \\
\left(\mathrm{kg} \mathrm{N}_{2} \mathrm{O}-\mathrm{Nha}^{-1} \mathrm{yr}^{-1}\right)\end{array}$ \\
\hline Ammann et al. (2009) & Low clover & 230 & 21 & 1.60 \\
\hline Ammann et al. (2009) & High clover & 0 & 32 & -0.10 \\
\hline Jensen et al. (2012) & Fertilised pasture & $\mathrm{n} / \mathrm{a}$ & 0 & 4.49 \\
\hline Jensen et al. (2012) & Unfertilised grass & 0 & 0 & 1.20 \\
\hline Jensen et al. (2012) & Grass-clover & 0 & $\mathrm{n} / \mathrm{a}$ & 0.54 \\
\hline Jensen et al. (2012) & Pure clover & 0 & 100 & 0.79 \\
\hline Klumpp et al. (2011) & Low clover & 157 & 19 & 1.72 \\
\hline Klumpp et al. (2011) & High clover & 157 & 35 & 1.52 \\
\hline Li et al. (2011) & Ryegrass grazed & 226 & 0 & 7.82 \\
\hline Li et al. (2011) & Fertilised ryegrass-white clover grazed & 58 & $20-25$ & 6.35 \\
\hline Li et al. (2011) & Unfertilised ryegrass-white clover grazed & 0 & $20-25$ & 6.54 \\
\hline Li et al. (2011) & Ryegrass background & 0 & 0 & 2.38 \\
\hline Li et al. (2011) & Grass-clover background & 0 & $20-25$ & 2.45 \\
\hline Schmeer et al. (2014) & Uncompacted grass & 360 & 15 & 8.74 \\
\hline Schmeer et al. (2014) & Compacted grass & 360 & 15 & 13.31 \\
\hline Schmeer et al. (2014) & Uncompacted lucerne grass & 0 & 70 & 2.46 \\
\hline Schmeer et al. (2014) & Compacted lucerne grass & 0 & 70 & 2.22 \\
\hline Šimek et al. (2004) & No clover & 210 & 0 & 2.28 \\
\hline Šimek et al. (2004) & High clover & 20 & 60 & 1.50 \\
\hline Šimek et al. (2004) & Pure clover & 20 & 100 & 1.50 \\
\hline This study 2015 & Low clover & 296 & 15 & 3.82 \\
\hline This study 2016 & Low clover & 181 & 4 & 6.27 \\
\hline This study 2015 & High clover & 0 & 21 & 1.89 \\
\hline This study 2016 & High clover & 0 & 44 & 4.07 \\
\hline Virkajärvi et al. (2010) & No clover & 220 & 0 & 3.65 \\
\hline Virkajärvi et al. (2010) & High clover & 0 & 75 & 7.00 \\
\hline
\end{tabular}

N/a - not applicable.

for annual estimates were filled with the arithmetic average because this method appropriately represents an average of peak and background emissions, rather than predominantly representing background emissions as with the running median method. In summary, our year-round measurements of $\mathrm{N}_{2} \mathrm{O}$ emissions are higher than the multi-site averages due to the fertiliser regime and site conditions, but within plausible ranges compared to other sites.

\section{2 $\quad \mathrm{N}_{2} \mathrm{O}$ emissions in the unfertilised clover parcel}

$\mathrm{N}_{2} \mathrm{O}$ emissions in the clover parcel during our 2-year observation period totaled 1.9 and $3.8 \mathrm{~kg} \mathrm{~N}_{2} \mathrm{O}-\mathrm{N} \mathrm{ha}^{-1} \mathrm{yr}^{-1}$ in 2015 and 2016, respectively. These $\mathrm{N}_{2} \mathrm{O}$ emissions were clearly lower than the values observed in the control parcel during both years. In 2015, the difference can be attributed to the difference in fertilisation between parcels, as the clover proportion was still similar in both parcels (control parcel: $15 \%$; clover parcel: $21 \%$ clover). In 2016, large differences in clover proportion (control parcel: $4 \%$; clover parcel: $44 \%$ clover) resulted in similarly lower $\mathrm{N}_{2} \mathrm{O}$ emis- sions on the clover parcel as in 2015 . However, $\mathrm{N}_{2} \mathrm{O}$ emissions in the clover parcel were high compared to other unfertilised grass-clover mixtures with zero or low fertiliser inputs $(<50 \mathrm{~kg} \mathrm{~N})$ for which average emissions of $0.54 \mathrm{~kg} \mathrm{~N}_{2} \mathrm{O}$ $\mathrm{N} \mathrm{ha}^{-1} \mathrm{yr}^{-1}\left(0.10-1.30 \mathrm{~kg} \mathrm{~N}_{2} \mathrm{O}-\mathrm{N} \mathrm{ha}^{-1} \mathrm{yr}^{-1}\right)$ were reported by Jensen et al. (2012) based on eight site years. Further nonfertilised grass-clover mixtures showed annual $\mathrm{N}_{2} \mathrm{O}$ emissions of up to $2.5 \mathrm{~kg} \mathrm{~N}_{2} \mathrm{O}-\mathrm{N} \mathrm{ha}^{-1} \mathrm{yr}^{-1}$ (Li et al., 2011; Table 5). Thus, our measurements exceeded the typical range of values in the second year by $50 \%$. Regular $\mathrm{N}$ amendments at the Chamau site in the past might have led to immobilisation of $\mathrm{N}$ via microbes and subsequent enrichment of the soil organic N (SON) pool (Conant et al., 2005; Ledgard et al., 1998). This in turn is known to lead to higher background $\mathrm{N}_{2} \mathrm{O}$ emissions in relation to $\mathrm{N}_{2} \mathrm{O}$ emissions observed from sites under long-term extensive management. In addition, high total $\mathrm{N}$ deposition $\left(\mathrm{NH}_{3}, \mathrm{NO}_{3}, \mathrm{HNO}_{3}, \mathrm{NO}_{2}\right)$ in the study area (in total $33.8 \mathrm{~kg} \mathrm{~N} \mathrm{ha}^{-1} \mathrm{yr}^{-1}$ in 2015; Rihm and Achermann, 2016) might foster background $\mathrm{N}_{2} \mathrm{O}$ emissions due to increased $\mathrm{NH}_{4}^{-+}$and $\mathrm{NO}_{3}^{-}$availability (Butterbach-Bahl et al., 2013). Additionally, $\mathrm{NH}_{3}$ deposition on the clover parcel 
originating from $\mathrm{NH}_{3}$ emissions from the adjacent control parcel is likely to be the cause of increased soil $\mathrm{NH}_{4}^{-+}$concentrations after the event on 17 August 2016. Furthermore, a possible explanation for the relatively high $\mathrm{N}_{2} \mathrm{O}$ emissions from our clover parcel in 2016 related to the meteorological conditions, which were wetter during summer and therefore more favourable for $\mathrm{N}_{2} \mathrm{O}$ production than during 2015 . High background $\mathrm{N}_{2} \mathrm{O}$ emissions in the clover parcel in 2016 were reflected by similarly high background $\mathrm{N}_{2} \mathrm{O}$ emissions in the control parcel, indicating that these were mainly driven by other factors (favourable meteorological conditions, sufficient $\mathrm{N}$ substrate availability) and not by the sward composition itself.

\subsection{Effects of management and environmental drivers on $\mathrm{N}_{2} \mathrm{O}$ emissions}

Our aim was to identify the main drivers of $\mathrm{N}_{2} \mathrm{O}$ emissions and therefore we investigated the effects of management (fertilisation, harvest, grazing, and over-sowing leading to increased clover proportion) and environmental variables on $\mathrm{N}_{2} \mathrm{O}$ emissions. Fertilisation of the control parcel had the largest effect on $\mathrm{N}_{2} \mathrm{O}$ emissions. Increased $\mathrm{N}$ availability due to fertilisation is widely known as a main driver of $\mathrm{N}_{2} \mathrm{O}$ emissions, which makes it a key factor for mitigating $\mathrm{N}_{2} \mathrm{O}$ emissions (Bouwman et al., 2002; Smith et al., 1997). Nevertheless, the effects of fertilisation on $\mathrm{N}_{2} \mathrm{O}$ emissions vary widely across grassland sites and years $(0.01 \%-3.56 \%$ in Flechard et al., 2007; 0.1\%-8.6\% in Hörtnagl et al., 2018; $1.4 \%$ and $3.5 \%$ of fertiliser $\mathrm{N}$ across years in this study), indicating that fertilisation alone is insufficient to explain $\mathrm{N}_{2} \mathrm{O}$ emissions and highlighting the need to take additional drivers into account. We further observed increased $\mathrm{N}_{2} \mathrm{O}$ emissions following harvest events on the control parcel, which may be explained as a consequence of increased rhizodeposition (Bolan et al., 2004; Butenschoen et al., 2008). Subsequently, greater availability of labile $\mathrm{C}$ compounds can lead to increased microbial activity, accompanied by increased production of $\mathrm{N}_{2} \mathrm{O}$ (Rudaz et al., 1999). Higher $\mathrm{N}_{2} \mathrm{O}$ fluxes following cutting were similarly observed on a pasture in central France (up to $3.7 \mathrm{mg} \mathrm{N}_{2} \mathrm{O}-\mathrm{N} \mathrm{m}^{-2} \mathrm{~d}^{-1}$ in Klumpp et al., 2011; up to $7.0 \mathrm{mg} \mathrm{N}_{2} \mathrm{O}-\mathrm{N} \mathrm{m}^{-2} \mathrm{~d}^{-1}$ in this study). Grazing had only a minor influence on the overall $\mathrm{N}_{2} \mathrm{O}$ budget of the Chamau site with $3.71 \%$ of $\mathrm{N}_{2} \mathrm{O}-\mathrm{N}$ emitted during grazing periods, and data analysis showed that $\mathrm{N}_{2} \mathrm{O}$ fluxes did not significantly respond to the presence of animals (Fig. 7c). We attribute this observation to low stocking densities and short duration of grazing (Table 1). Other studies with higher stocking densities have shown that more intensive grazing led to increased $\mathrm{N}_{2} \mathrm{O}$ emissions (van Groenigen et al., 2005; Oenema et al., 1997). These were attributed to $\mathrm{C}$ and $\mathrm{N}$ from animal excreta and to soil compaction by treading and trampling animals, creating anaerobic soil conditions (Flechard et al., 2007; Lampe et al., 2006; Oenema et al., 1997).
An important finding from this study is that increased clover proportion, and subsequently increased BFN, did not increase $\mathrm{N}_{2} \mathrm{O}$ emissions, as shown by comparing $\mathrm{N}_{2} \mathrm{O}$ emissions between the two parcels during periods without management (Table 5c, Clo-0). In other words, substrate from the decomposition of plant residues and from root exudates may affect $\mathrm{N}_{2} \mathrm{O}$ emissions, but this effect was similar on both parcels, independent of the higher clover proportion and BFN in the clover parcel. This is in contrast to a study on a boreal grass-clover mixture in which significant $\mathrm{N}_{2} \mathrm{O}$ emissions were observed in spring, largely exceeding the fertilised grassland control (Virkajärvi et al., 2010). These higher emissions were explained by increased substrate available to microbial communities producing $\mathrm{N}_{2} \mathrm{O}$ in the surface layer after spring thaw (Wagner-Riddle et al., 2008). Nitrous oxide emissions from BNF itself (rhizobial denitrification) have been shown to be possible (O'Hara and Daniel, 1985). Nevertheless, due to its small magnitude the contribution to field-scale $\mathrm{N}_{2} \mathrm{O}$ emissions is negligible (Rochette and Janzen, 2005). Previous results from a laboratory incubation by Carter and Ambus (2006), who investigated $\mathrm{N}_{2} \mathrm{O}$ emissions from unfertilised soils for up to 36 weeks, showed that recently fixed $\mathrm{N}_{2}$ in a white clover-ryegrass mixture contributed as little as $2.1 \pm 0.5 \%$ to total $\mathrm{N}_{2} \mathrm{O}$ emissions. In agreement with our result, measurements from permanent grasslands in Ireland, where winter freeze-thaw cycles are very rare, showed that annual $\mathrm{N}_{2} \mathrm{O}$ emissions in unfertilised ryegrass $\left(2.38 \pm 0.12 \mathrm{~kg} \mathrm{~N}_{2} \mathrm{O}-\mathrm{N} \mathrm{ha}^{-1} \mathrm{yr}^{-1}\right)$ were not significantly different from an unfertilised grass-clover sward $\left(2.45 \pm 0.85 \mathrm{~kg} \mathrm{~N}_{2} \mathrm{O}-\mathrm{N} \mathrm{ha}^{-1} \mathrm{yr}^{-1}\right)$ with clover proportions of $20-25 \%$, hence providing evidence that $\mathrm{N}_{2} \mathrm{O}$ emission due to $\mathrm{BNF}$ itself and clover residual decomposition were negligible (Li et al., 2011). Our findings are in line with these observations and add the insight that clover proportions of up to $44 \%$, as found in our study, will not result in increased $\mathrm{N}_{2} \mathrm{O}$ emissions.

The effects of temperature and soil water content on $\mathrm{N}_{2} \mathrm{O}$ emissions as found in our study are in line with established knowledge (Butterbach-Bahl et al., 2013; Flechard et al., 2007). Furthermore, directly measured soil oxygen concentrations, which have hardly been used in field-scale studies before, improved the prediction of $\mathrm{N}_{2} \mathrm{O}$ emissions (Table 4). Our data showed that larger plant $\mathrm{C}$ uptake (negative NEE) of $\mathrm{CO}_{2}$ as a proxy for plant activity was associated with reduced $\mathrm{N}_{2} \mathrm{O}$ emissions, which supports the hypothesis that plant roots are in competition for available $\mathrm{N}$ with microbes and often reduce the $\mathrm{N}$ availability to microbes (Merbold et al., 2014). Thus, we observed lower $\mathrm{N}_{2} \mathrm{O}$ emissions at higher levels of photosynthesis. Our analysis showed that inclusion of $\mathrm{NH}_{4}^{+}-\mathrm{N}$ concentration in the statistical analysis improved the prediction of $\mathrm{N}_{2} \mathrm{O}$ emissions, while $\mathrm{NO}_{3}^{-}-\mathrm{N}$ and DOC were of less importance for the prediction of $\mathrm{N}_{2} \mathrm{O}$ emissions. Comparable results for the influence of $\mathrm{NH}_{4}^{+}$and $\mathrm{NO}_{3}^{-}$were found at an Irish grassland (Rafique et al., 2012). In summary, fertilisation was the dominant predictor of $\mathrm{N}_{2} \mathrm{O}$ emis- 
sions, while soil temperature, soil water content, soil oxygen concentration, and NEE of $\mathrm{CO}_{2}$ were significant environmental drivers. Concluding from all management effects, the decrease in annual $\mathrm{N}_{2} \mathrm{O}$ emissions under the mitigation strategy was primarily caused by the absence of fertilisation, while a potential effect of the increase in clover proportion and increased BFN offsetting these emission reductions was absent.

\subsection{Effect of the mitigation strategy on productivity and biological nitrogen fixation}

An important precondition for the acceptance of any climate change mitigation strategy is that yields need to be maintained at similar levels as under conventional management. Differences in biomass yields between the control and clover parcels were only minor (19\% and $9 \%$ lower in the clover parcel in 2015 and 2016, respectively) and comparable to the observed differences between the two parcels prior to the mitigation experiment (Table S2). Maintaining high yields without fertilisation can be explained by the increased BFN in the clover parcel and positive interactions between clover and grass ("overyielding effect") (Lüscher et al., 2014; Nyfeler et al., 2009). Additionally, high SON content due to the previous year's fertiliser amendments are expected to contribute to the persistently high production levels (Table 2). Similar productivity levels of an unfertilised grass-clover mixture (three cuts, 9\% less DM) compared to an adjacent intensive grass-clover mixture $(230 \mathrm{~kg} \mathrm{~N}$ fertiliser, 4-5 cuts) were also found at a site $50 \mathrm{~km}$ from the Chamau field site in the past (Ammann et al., 2009). Furthermore, our findings are consistent with findings from the more comprehensive study by Nyfeler et al. (2009), who found large overyielding effects in comparable Swiss grassland systems; i.e. grass-clover yields at $50 \mathrm{~kg} \mathrm{~N} \mathrm{ha}^{-1} \mathrm{yr}^{-1}$ and $50 \%$ to $70 \%$ clover were as productive as grass monocultures fertilised with $450 \mathrm{~kg} \mathrm{Nha}^{-1} \mathrm{yr}^{-1}$. The overyielding effect has been reported across a wide range of climates and soil types (Finn et al., 2013; Kirwan et al., 2007), indicating that our result of maintained productivity levels under the mitigation strategy is likely to be reproducible across a wider range of site conditions.

Biologically fixed nitrogen found in shoot biomass was slightly higher in the clover parcel $\left(72 \mathrm{~kg} \mathrm{~N} \mathrm{ha}^{-1} \mathrm{yr}^{-1}\right)$ compared to the control parcel $\left(55 \mathrm{~kg} \mathrm{Nha}^{-1} \mathrm{yr}^{-1}\right)$ in 2015 due to only small differences in clover proportion between the two parcels. During the second year, over-sowing was more effective and BFN found in shoot biomass in the clover parcel totaled $130 \mathrm{~kg} \mathrm{Nha}^{-1} \mathrm{yr}^{-1}$, while only $14 \mathrm{~kg} \mathrm{~N} \mathrm{ha}^{-1} \mathrm{yr}^{-1}$ was measured in the control parcel. Previous studies reported similar amounts of BFN for mown and grazed pasture systems (Ledgard and Steele, 1992; Nyfeler et al., 2011), with maxima being as high as $323 \mathrm{~kg} \mathrm{~N} \mathrm{ha}^{-1} \mathrm{yr}^{-1}$ as observed in a comparable grass-clover mixture (Nyfeler et al., 2011). This indicates that biologically fixed nitrogen at Chamau could reach higher amounts than observed during our experiment. Clover proportions at our site varied seasonally, with a minimum in spring and maximum in summer in both parcels. Such seasonal cycles in clover proportions occur due to species' developmental cycles, but also the competitive advantages and disadvantages of the respective species. Drier conditions, observed for instance in summer (JJA), result in competitive advantages of the clover compared to grasses, as $\mathrm{N}_{2}$ fixation is less sensitive to dry conditions than uptake of mineral N (Hofer et al., 2017; Lüscher et al., 2005). Furthermore, inter-annual variability of clover proportions can be an additional management challenge for farmers whose aim is to keep a persistent sward composition (Lüscher et al., 2014).

Lower SON content $\left(3490 \mathrm{~kg} \mathrm{Nha}^{-1}\right)$ in a grass-clover mixture compared to a $200 \mathrm{~kg} \mathrm{ha}^{-1} \mathrm{yr}^{-1}$ fertilised grassland $\left(4350 \mathrm{~kg} \mathrm{Nha}^{-1}\right)$ was observed after 13 years of management comparable to our experiment (Ledgard et al., 1998). It is well known that $\mathrm{N}$ exports exceeding inputs leads to a decreasing SON pool. Potential losses in SON were shown to be closely linked to losses in soil organic C (SOC) (Ammann et al., 2009; Conant et al., 2005) and can therefore compromise the soil's $\mathrm{CO}_{2}$ sink strength. Thus, detailed investigations on the effect of the clover treatment on SON, SOC content, and $\mathrm{CO}_{2}$ exchange are recommended to comprehensively evaluate the mitigation strategy in the long term.

\subsection{Effect of the mitigation strategy on $\mathrm{N}_{2} \mathrm{O}$ emissions and emission intensities}

We found that the mitigation strategy effectively reduced $\mathrm{N}_{2} \mathrm{O}$ emissions by $54 \%(51 \%-57 \%)$ and $39 \%(36 \%-42 \%)$ in 2015 and 2016 as well as $\mathrm{N}_{2} \mathrm{O}$ emission intensities by $41 \%$ and $30 \%$ in 2015 and 2016, respectively. Past studies carried out in temperate grasslands consistently found reductions in $\mathrm{N}_{2} \mathrm{O}$ emissions when reducing fertiliser and increasing BFN through legumes (Table 5). The magnitude of relative $\mathrm{N}_{2} \mathrm{O}$ emission reductions ranged from $34 \%$ (Šimek et al., 2004) to $100 \%$ (Ammann et al., 2009), with absolute $\mathrm{N}_{2} \mathrm{O}$ emission reductions of $0.8 \mathrm{~kg} \mathrm{~N} \mathrm{ha}^{-1} \mathrm{yr}^{-1}$ (Šimek et al., 2004) to $11.1 \mathrm{~kg} \mathrm{Nha}^{-1} \mathrm{yr}^{-1}$ (Schmeer et al., 2014). The variability across studies can be attributed to differences in meteorological and soil conditions as well as variations in the experimental set-up (i.e. fertiliser rates applied, realised legume proportions, grass and legume species; Table 5). Much higher $\mathrm{N}_{2} \mathrm{O}$ emissions from an unfertilised grassclover mixture ( $92 \%$ increase) compared to $\mathrm{N}_{2} \mathrm{O}$ emissions from a grass sward fertilised with $220 \mathrm{~kg} \mathrm{~N} \mathrm{ha}^{-1} \mathrm{yr}^{-1}$ were observed under boreal climate conditions in eastern Finland due to large springtime emissions associated with freezethaw cycles (Virkajärvi et al., 2010). Such an effect could not be found at our site, although soils also freeze occasionally during the cold season, but at most in the top few centimetres. Although our tested mitigation strategy seems to be beneficial for permanent grasslands, Basche et al. (2014) and Lugato et al. (2018) have shown that incorporation of clover 
into the soil may lead to increased $\mathrm{N}_{2} \mathrm{O}$ fluxes and thus may not be the best mitigation strategy for croplands and temporary grasslands for which ploughing is done much more frequently.

In summary, the implementation of the mitigation option tested here was found to be effective at permanent grassland in the temperate zone. It is cheap and simple as it requires few management activities, which would favour farmer willingness for implementation (Vellinga et al., 2011).

Data availability. Data will be deposited at the ETH Zurich research collection, see http://hdl.handle.net/20.500.11850/289359 (Fuchs, 2018).

Supplement. The supplement related to this article is available online at: https://doi.org/10.5194/bg-15-5519-2018-supplement.

Author contributions. KF and LM designed the project and performed the field experiment. LH assisted with post-processing of EC data. KF performed the statistical analyses. WE, NB, and VS commented on the experimental design and the results of the data analysis. KF wrote and revised the manuscript, with contributions and feedback by LM, LH, WE, NB, and VS.

Competing interests. The authors declare that they have no conflict of interest.

Acknowledgements. This study was carried out within the framework of FACCE-JPI in the Models4Pastures project with the Swiss contribution funded by the Swiss National Science Foundation (SNSF; contract number 40FA40_154245) and the New Zealand contribution funded by the New Zealand government to support the objectives of the Livestock Research Group of the Global Research Alliance for Agricultural Greenhouse Gases - Integrative Research Group (http://globalresearchalliance.org/research/integrative, last access: 5 September 2018). We gratefully acknowledge the Models4Pastures project team for enriching discussions on the measured data. We are thankful for the support provided by the head of the former ETH research station, Chamau Hans-Rudolf Wettstein, and the staff on site: Ivo Widmer, Tina Stiefel, and Meinrad Stalder. We are particularly grateful to Britta Jahn-Humphrey for conducting the DOC analysis and to Annika Ackermann and Roland A. Werner for the $\mathrm{C}, \mathrm{N}$, and ${ }^{15} \mathrm{~N}$ isotope analyses. We are very thankful to Florian Käslin and Patrick Koller for technical assistance in the experimental work and oxygen sensor development. Further thanks go to our colleagues Charlotte Decock and Elisabeth Verhoeven from the Sustainable Agroecosystems research group at ETH for laboratory introductions and valuable advice at the beginning of the experiment. We thank Natascha Kljun for useful discussions on the footprint parameterisation and Beat Rihm for providing $\mathrm{N}$ deposition estimates for the study site. Valuable practical support in biomass and soil sampling as well as processing during the experiment was given by interns Astrid Riemer and
Manjunatha Chandregowda and student assistant Reto Zihlmann.

Edited by: Kees Jan van Groenigen

Reviewed by: Ute Skiba and two anonymous referees

\section{References}

Ammann, C., Spirig, C., Leifeld, J., and Neftel, A.: Assessment of the nitrogen and carbon budget of two managed temperate grassland fields, Agr. Ecosyst. Environ., 133, 150-162, https://doi.org/10.1016/j.agee.2009.05.006, 2009.

Basche, A. D., Miguez, F. E., Kaspar, T. C., and Castellano, M. J.: Do cover crops increase or decrease nitrous oxide emissions? A meta-analysis, J. Soil Water Conserv., 69, 471-482, https://doi.org/10.2489/jswc.69.6.471, 2014.

Bell, M. J., Hinton, N., Cloy, J. M., Topp, C. F. E., Rees, R. M., Cardenas, L., Scott, T., Webster, C., Ashton, R. W., Whitmore, A. P., Williams, J. R., Balshaw, H., Paine, F., Goulding, K. W. T., and Chadwick, D. R.: Nitrous oxide emissions from fertilised UK arable soils: Fluxes, emission factors and mitigation, Agr. Ecosyst. Environ., 212, 134-147, https://doi.org/10.1016/j.agee.2015.07.003, 2015.

Biermann, T., Babel, W., Ma, W., Chen, X., Thiem, E., Ma, Y., and Foken, T.: Turbulent flux observations and modelling over a shallow lake and a wet grassland in the Nam Co basin, Tibetan Plateau, Theor. Appl. Climatol., 116, 301-316, https://doi.org/10.1007/s00704-013-0953-6, 2014.

Boddey, R. M., Peoples, M. B., Palmer, B., and Dart, P. J.: Use of the ${ }^{15} \mathrm{~N}$ natural abundance technique to quantify biological nitrogen fixation by woody perennials, Nutr. Cycl. Agroecosys., 57, 235270, https://doi.org/10.1023/A:1009890514844, 2000.

Bolan, N. S., Saggar, S., Luo, J., Bhandral, R., and Singh, J.: Gaseous emissions of nitrogen from grazed pastures: Processes, measurements and modelling, environmental implications, and mitigation, Vol. 84, Advances in Agronomy, 37-120, Academic Press, San Diego, 2004.

Bouwman, A. F., Boumans, L. J. M., and Batjes, N. H.: Emissions of $\mathrm{N}_{2} \mathrm{O}$ and $\mathrm{NO}$ from fertilized fields: Summary of available measurement data, Global Biogeochem. Cy., 16, 6-1-6-13, https://doi.org/10.1029/2001GB001811, 2002.

Burri, S., Sturm, P., Prechsl, U. E., Knohl, A., and Buchmann, N.: The impact of extreme summer drought on the short-term carbon coupling of photosynthesis to soil $\mathrm{CO}_{2}$ efflux in a temperate grassland, Biogeosciences, 11, 961-975, https://doi.org/10.5194/bg-11-961-2014, 2014.

Butenschoen, O., Marhan, S., and Scheu, S.: Response of soil microorganisms and endogeic earthworms to cutting of grassland plants in a laboratory experiment, Appl. Soil Ecol., 38, 152-160, https://doi.org/10.1016/j.apsoil.2007.10.004, 2008.

Butterbach-Bahl, K., Baggs, E. M., Dannenmann, M., Kiese, R., and Zechmeister-Boltenstern, S.: Nitrous oxide emissions from soils: how well do we understand the processes and their controls?, Philos. T. R. Soc. B, 368, 20130122, https://doi.org/10.1098/rstb.2013.0122, 2013.

Carlsson, G. and Huss-Danell, K.: Does nitrogen transfer between plants confound ${ }^{15} \mathrm{~N}$-based quantifications of $\mathrm{N}_{2}$ fixation?, Plant Soil, 374, 345-358, https://doi.org/10.1007/s11104-013-1802-1, 2014. 
Carter, M. S. and Ambus, P.: Biologically fixed $\mathrm{N}_{2}$ as a source for $\mathrm{N}_{2} \mathrm{O}$ production in a grass-clover mixture, measured by ${ }^{15} \mathrm{~N}_{2}$, Nutr. Cycl. Agroecosys., 74, 13-26, https://doi.org/10.1007/s10705-005-4111-0, 2006.

Conant, R. T., Paustian, K., Grosso, S. J. D., and Parton, W. J.: Nitrogen pools and fluxes in grassland soils sequestering carbon, Nutr. Cycl. Agroecosys., 71, 239-248, https://doi.org/10.1007/s10705-004-5085-z, 2005.

Crews, T. E. and Peoples, M. B.: Can the synchrony of nitrogen supply and crop demand be improved in legume and fertilizerbased agroecosystems? A review, Nutr. Cycl. Agroecosys., 72, 101-120, https://doi.org/10.1007/s10705-004-6480-1, 2005.

de Klein, C. a. M. and Eckard, R. J.: Targeted technologies for nitrous oxide abatement from animal agriculture, Aust. J. Exp. Agr., 48, 14-20, https://doi.org/10.1071/EA07217, 2008.

Dewhurst, R. J., Fisher, W. J., Tweed, J. K. S., and Wilkins, R. J.: Comparison of grass and legume silages for milk production. 1. Production responses with different levels of concentrate, J. Dairy Sci., 86, 2598-2611, https://doi.org/10.3168/jds.S00220302(03)73855-7, 2003

Eugster, W. and Merbold, L.: Eddy covariance for quantifying trace gas fluxes from soils, SOIL, 1, 187-205, https://doi.org/10.5194/soil-1-187-2015, 2015.

Eugster, W. and Plüss, P.: A fault-tolerant eddy covariance system for measuring $\mathrm{CH}_{4}$ fluxes, Agr. Forest Meteorol., 150, 841-851, https://doi.org/10.1016/j.agrformet.2009.12.008, 2010.

Eugster, W. and Zeeman, M. J.: Micrometeorological techniques to measure ecosystem-scale greenhouse gas fluxes for model validation and improvement, Int. Congr. Ser., 1293, 66-75, https://doi.org/10.1016/j.ics.2006.05.001, 2006.

Finn, J. A., Kirwan, L., Connolly, J., Sebastià, M. T., Helgadottir, A., Baadshaug, O. H., Bélanger, G., Black, A., Brophy, C., Collins, R. P., Čop, J., Dalmannsdóttir, S., Delgado, I., Elgersma, A., Fothergill, M., Frankow-Lindberg, B. E., Ghesquiere, A., Golinska, B., Golinski, P., Grieu, P., Gustavsson, A.-M., Höglind, M., Huguenin-Elie, O., Jørgensen, M., Kadziuliene, Z., Kurki, P., Llurba, R., Lunnan, T., Porqueddu, C., Suter, M., Thumm, U., and Lüscher, A.: Ecosystem function enhanced by combining four functional types of plant species in intensively managed grassland mixtures: a 3-year continental-scale field experiment, edited by: Wilsey, B., J. Appl. Ecol., 50, 365-375, https://doi.org/10.1111/1365-2664.12041, 2013.

Flechard, C. R., Ambus, P., Skiba, U., Rees, R. M., Hensen, A., van Amstel, A., van den Pol-van Dasselaar, A., Soussana, J.F., Jones, M., Clifton-Brown, J., Raschi, A., Horvath, L., Neftel, A., Jocher, M., Ammann, C., Leifeld, J., Fuhrer, J., Calanca, P., Thalman, E., Pilegaard, K., Di Marco, C., Campbell, C., Nemitz, E., Hargreaves, K. J., Levy, P. E., Ball, B. C., Jones, S. K., van de Bulk, W. C. M., Groot, T., Blom, M., Domingues, R., Kasper, G., Allard, V., Ceschia, E., Cellier, P., Laville, P., Henault, C., Bizouard, F., Abdalla, M., Williams, M., Baronti, S., Berretti, F., and Grosz, B.: Effects of climate and management intensity on nitrous oxide emissions in grassland systems across Europe, Agr. Ecosyst. Environ., 121, 135-152, https://doi.org/10.1016/j.agee.2006.12.024, 2007.

Flessa, H.: Studie zur Vorbereitung einer effizienten und gut abgestimmten Klimaschutzpolitik für den Agrarsektor, Johann Heinrich von Thünen-Institut, Braunschweig, available at: https:// literatur.thuenen.de/digbib_extern/dn050716.pdf (last access: 28 July 2018), 2012.

Foken, T. and Wichura, B.: Tools for quality assessment of surfacebased flux measurements, Agr. Forest Meteorol., 78, 83-105, https://doi.org/10.1016/0168-1923(95)02248-1, 1996.

Foken, T., Gockede, M., Mauder, M., Mahrt, L., Amiro, B., and Munger, J.: Post field data quality control, in: Handbook of Micrometeorology: A guide for surface flux measurements and analysis, edited by: Lee, X., Massmann, W., and Law, B., 181208, Kluwer, Dordrecht, 2004.

Fratini, G., Ibrom, A., Arriga, N., Burba, G., and Papale, D.: Relative humidity effects on water vapour fluxes measured with closed-path eddy-covariance systems with short sampling lines, Agr. Forest Meteorol., 165, 53-63, https://doi.org/10.1016/j.agrformet.2012.05.018, 2012.

Fuchs, K.: Dataset from the Chamau Nitrous Oxide Mitigation Experiment 2015-2016, ETH Zurich Research Collection, https://doi.org/10.3929/ethz-b-000289359, last access: 14 September 2018.

Galloway, J. N., Aber, J. D., Erisman, J. W. Seitzinger, S. P., Howarth, R. W., Cowling, E. B., and Cosby, B. J.: The Nitrogen Cascade, BioScience, 53, 341-356, https://doi.org/10.1641/00063568(2003)053[0341:TNC]2.0.CO;2, 2003.

Garcia-Plazaola, J. I., Becerril, J. M., Arrese-Igor, C., GonzalezMurua, C., and Aparicio-Tejo, P. M.: The contribution of Rhizobium meliloti to soil denitrification, Plant Soil, 157, 207-213, https://doi.org/10.1007/BF00011049, 1993.

Gourlez de la Motte, L., Mamadou, O., Beckers, Y., Bodson, B., Heinesch, B., and Aubinet, M.: Rotational and continuous grazing does not affect the total net ecosystem exchange of a pasture grazed by cattle but modifies $\mathrm{CO}_{2}$ exchange dynamics, Agr. Ecosyst. Environ., 253, 157-165, https://doi.org/10.1016/j.agee.2017.11.011, 2018.

Guckert, A. and Hay, R. K. M.: The overwintering, spring growth, and yield in mixed species swards of white clover in Europe, Ann. Bot., 88, 667-668, https://doi.org/10.1006/anbo.2001.1508, 2001.

Hofer, D., Suter, M., Buchmann, N., and Lüscher, A.: Nitrogen status of functionally different forage species explains resistance to severe drought and post-drought overcompensation, Agr. Ecosyst. Environ., 236, 312-322, https://doi.org/10.1016/j.agee.2016.11.022, 2017.

Horst, T. W.: A simple formula for attenuation of eddy fluxes measured with first-order-response scalar sensors, Bound.-Lay. Meteorol., 82, 219-233, https://doi.org/10.1023/A:1000229130034, 1997.

Horst, T. W. and Lenschow, D. H.: Attenuation of scalar fluxes measured with spatially-displaced sensors, Bound.-Lay. Meteorol., 130, 275-300, https://doi.org/10.1007/s10546-008-9348-0, 2009.

Hörtnagl, L., Barthel, M., Buchmann, N., Eugster, W., ButterbachBahl, K., Díaz-Pinés, E., Zeeman, M., Klumpp, K., Kiese, R., Bahn, M., Hammerle, A., Lu, H., Ladreiter-Knauss, T., Burri, S., and Merbold, L.: Greenhouse gas fluxes over managed grasslands in Central Europe, Glob. Change Biol., 24, 1843-1872, https://doi.org/10.1111/gcb.14079, 2018.

Huhtanen, P., Rinne, M., and Nousiainen, J.: Evaluation of the factors affecting silage intake of dairy cows: a revision of the 
relative silage dry-matter intake index, Animal, 1, 758-770, https://doi.org/10.1017/S175173110773673X, 2007.

Imer, D., Merbold, L., Eugster, W., and Buchmann, N.: Temporal and spatial variations of soil $\mathrm{CO}_{2}, \mathrm{CH}_{4}$ and $\mathrm{N}_{2} \mathrm{O}$ fluxes at three differently managed grasslands, Biogeosciences, 10, 5931-5945, https://doi.org/10.5194/bg-10-5931-2013, 2013.

IPCC (Ciais, P., Sabine, C., Bala, G., Bopp, L., Brovkin, V., Canadell, J., Chhabra, A., DeFries, R., Galloway, J., Heimann, M., Jones, C., Le Quéré, C., Myneni, R. B., Piao, S., and Thornton, P.): Carbon and Other Biogeochemical Cycles, in: Climate Change 2013: The Physical Science Basis. Contribution of Working Group I to the Fifth Assessment Report of the Intergovernmental Panel on Climate Change, edited by: Stocker, T. F., Qin, D., Plattner, G.-K., Tignor, M., Allen, S. K., Boschung, J., Nauels, A., Xia, Y., Bex, V., and Midgley, P. M., Cambridge University Press, Cambridge, UK and New York, NY, USA, 2013a.

IPCC (Myhre, G., Shindell, D., Bréon, F.-M., Collins, W., Fuglestvedt, J., Huang, J., Koch, D., Lamarque, J.-F., Lee, D., Mendoza, B., Nakajima, T., Robock, A., Stephens, G., Takemura, T., and Zhang, H.): Anthropogenic and Natural Radiative Forcing, in: Climate Change 2013: The Physical Science Basis. Contribution of Working Group I to the Fifth Assessment Report of the Intergovernmental Panel on Climate Change, edited by: Stocker, T. F., Qin, D., Plattner, G.-K., Tignor, M., Allen, S. K., Boschung, J., Nauels, A., Xia, Y., Bex, V., and Midgley, P. M., Cambridge University Press, Cambridge, UK and New York, NY, USA, 2013b.

IPCC (Smith P., Bustamante, M., Ahammad, H., Clark, H., Dong, H., Elsiddig, E. A., Haberl, H., Harper, R., House, J., Jafari, M., Masera, O., Mbow, C., Ravindranath, N. H., Rice, C. W., Robledo Abad, C., Romanovskaya, A., Sperling, F., and Tubiello, F.): Agriculture, Forestry and Other Land Use (AFOLU), in: Climate Change 2014: Mitigation of Climate Change. Contribution of Working Group III to the Fifth Assessment Report of the Intergovernmental Panel on Climate Change, edited by: Edenhofer, O., Pichs-Madruga, R., Sokona, Y., Farahani, E., Kadner, S., Seyboth, K., Adler, A., Baum, I., Brunner, S., Eickemeier, P., Kriemann, B., Savolainen, J., Schlömer, S., von Stechow, C., Zwickel, T., and Minx, J. C., Cambridge University Press, Cambridge, UK and New York, NY, USA, 2014.

Jensen, E. S., Peoples, M. B., Boddey, R. M., Gresshoff, P. M., Hauggaard-Nielsen, H., Alves, B. J. R., and Morrison, M. J.: Legumes for mitigation of climate change and the provision of feedstock for biofuels and biorefineries. A review, Agron. Sustain. Dev., 32, 329-364, https://doi.org/10.1007/s13593-0110056-7, 2012.

Kirwan, L., Luescher, A., Sebastia, M. T., Finn, J. A., Collins, R. P., Porqueddu, C., Helgadottir, A., Baadshaug, O. H., Brophy, C., Coran, C., Dalmannsdottir, S., Delgado, I., Elgersma, A., Fothergill, M., Frankow-Lindberg, B. E., Golinski, P., Grieu, P., Gustavsson, A. M., Hoglind, M., Huguenin-Elie, O., Iliadis, C., Jorgensen, M., Kadziuliene, Z., Karyotis, T., Lunnan, T., Malengier, M., Maltoni, S., Meyer, V., Nyfeler, D., NykanenKurki, P., Parente, J., Smit, H. J., Thumm, U., and Connolly, J.: Evenness drives consistent diversity effects in intensive grassland systems across 28 European sites, J. Ecol., 95, 530-539, https://doi.org/10.1111/j.1365-2745.2007.01225.x, 2007.

Kljun, N., Calanca, P., Rotach, M. W., and Schmid, H. P.: A simple two-dimensional parameterisation for Flux Foot- print Prediction (FFP), Geosci. Model Dev., 8, 3695-3713, https://doi.org/10.5194/gmd-8-3695-2015, 2015.

Klumpp, K., Bloor, J. M. G., Ambus, P., and Soussana, J.-F.: Effects of clover density on $\mathrm{N}_{2} \mathrm{O}$ emissions and plant-soil $\mathrm{N}$ transfers in a fertilised upland pasture, Plant Soil, 343, 97-107, https://doi.org/10.1007/s11104-010-0526-8, 2011.

Lampe, C., Dittert, K., Sattelmacher, B., Wachendorf, M., Loges, R., and Taube, F.: Sources and rates of nitrous oxide emissions from grazed grassland after application of ${ }^{15} \mathrm{~N}$-labelled mineral fertilizer and slurry, Soil Biol. Biochem., 38, 2602-2613, https://doi.org/10.1016/j.soilbio.2006.03.016, 2006.

Ledgard, S. F. and Steele, K. W.: Biological nitrogen fixation in mixed legume/grass pastures, Plant Soil, 141, 137-153, https://doi.org/10.1007/BF00011314, 1992.

Ledgard, S. F., Jarvis, S. C., and Hatch, D. J.: Short-term nitrogen fluxes in grassland soils under different long-term nitrogen management regimes, Soil Biol. Biochem., 30, 1233-1241, https://doi.org/10.1016/S0038-0717(98)00022-4, 1998.

Ledgard, S. F., Sprosen, M. S., Penno, J. W., and Rajendram, G. S.: Nitrogen fixation by white clover in pastures grazed by dairy cows: Temporal variation and effects of nitrogen fertilization, Plant Soil, 229, 177-187, https://doi.org/10.1023/A:1004833804002, 2001.

Lenschow, D. H., Mann, J., and Kristensen, L.: How long is long enough when measuring fluxes and other turbulence statistics?, J. Atmos. Ocean. Tech., 11, 661-673, https://doi.org/10.1175/15200426(1994)011<0661:HLILEW>2.0.CO;2, 1994.

Li, D., Lanigan, G., and Humphreys, J.: Measured and simulated nitrous oxide emissions from ryegrass- and ryegrass/white cloverbased grasslands in a moist temperate climate, PLoS ONE, 6, e26176, https://doi.org/10.1371/journal.pone.0026176, 2011.

Li, D., Watson, C. J., Yan, M. J., Lalor, S., Rafique, R., Hyde, B., Lanigan, G., Richards, K. G., Holden, N. M., and Humphreys, J.: A review of nitrous oxide mitigation by farm nitrogen management in temperate grassland-based agriculture, J. Environ. Manage., 128, 893-903, https://doi.org/10.1016/j.jenvman.2013.06.026, 2013.

Lipper, L., Thornton, P., Campbell, B. M., Baedeker, T., Braimoh, A., Bwalya, M., Caron, P., Cattaneo, A., Garrity, D., Henry, K., Hottle, R., Jackson, L., Jarvis, A., Kossam, F., Mann, W., McCarthy, N., Meybeck, A., Neufeldt, H., Remington, T., Sen, P. T., Sessa, R., Shula, R., Tibu, A., and Torquebiau, E. F.: Climatesmart agriculture for food security, Nature Climate Change, 4, 1068-1072, https://doi.org/10.1038/nclimate2437, 2014.

Lugato, E., Leip, A., and Jones, A.: Mitigation potential of soil carbon management overestimated by neglecting $\mathrm{N}_{2} \mathrm{O}$ emissions, Nature Climate Change, 8, 219-223, https://doi.org/10.1038/s41558-018-0087-z, 2018.

Luo, J., de Klein, C. A. M., Ledgard, S. F., and Saggar, S.: Management options to reduce nitrous oxide emissions from intensively grazed pastures: A review, Agriculture, Ecosyst. Environ., 136, 282-291, https://doi.org/10.1016/j.agee.2009.12.003, 2010.

Lüscher, A., Fuhrer, J., and Newton, P. C. D.: Global atmospheric change and its effect on managed grassland systems, edited by: McGilloway, D. A., Wageningen Academic Publishers, Wageningen, 2005.

Lüscher, A., Mueller-Harvey, I., Soussana, J. F., Rees, R. M., and Peyraud, J. L.: Potential of legume-based grassland-livestock 
systems in Europe: a review, Grass Forage Sci., 69, 206-228, https://doi.org/10.1111/gfs.12124, 2014.

Mauder, M. and Foken, T.: Documentation and instruction manual of the eddy covariance software package TK2, Work Report, University of Bayreuth, Bayreuth, 2004.

Merbold, L., Eugster, W., Stieger, J., Zahniser, M., Nelson, D., and Buchmann, N.: Greenhouse gas budget $\left(\mathrm{CO}_{2}\right.$, $\mathrm{CH}_{4}$ and $\mathrm{N}_{2} \mathrm{O}$ ) of intensively managed grassland following restoration, Glob. Change Biol., 20, 1913-1928, https://doi.org/10.1111/gcb.12518, 2014.

Millar, N., Ndufa, J. K., Cadisch, G., and Baggs, E. M.: Nitrous oxide emissions following incorporation of improved-fallow residues in the humid tropics, Global Biogeochem. Cy., 18, GB1032, https://doi.org/10.1029/2003GB002114, 2004.

Moncrieff, J., Clement, R., Finnigan, J. J., and Meyers, T.: Averaging, detrending, and filtering of eddy covariance time series, in Handbook of micrometeorology: a guide for surface flux measurement and analysis, 29, edited by: Law, B. E., Lee, X., and Massmann, W. J., 7-31, Kluwer Academic, Dordrecht, 2004.

Neftel, A., Spirig, C., and Ammann, C.: Application and test of a simple tool for operational footprint evaluations, Environ. Pollut., 152, 644-652, https://doi.org/10.1016/j.envpol.2007.06.062, 2008.

Niklaus, P. A., Le Roux, X., Poly, F., Buchmann, N., SchererLorenzen, M., Weigelt, A., and Barnard, R. L.: Plant species diversity affects soil-atmosphere fluxes of methane and nitrous oxide, Oecologia, 181, 919-930, https://doi.org/10.1007/s00442016-3611-8, 2016.

Nyfeler, D., Huguenin-Elie, O., Suter, M., Frossard, E., Connolly, J., and Lüscher, A.: Strong mixture effects among four species in fertilized agricultural grassland led to persistent and consistent transgressive overyielding, J. Appl. Ecol., 46, 683-691, https://doi.org/10.1111/j.1365-2664.2009.01653.x, 2009.

Nyfeler, D., Huguenin-Elie, O., Suter, M., Frossard, E., and Lüscher, A.: Grass-legume mixtures can yield more nitrogen than legume pure stands due to mutual stimulation of nitrogen uptake from symbiotic and nonsymbiotic sources, Agr. Ecosyst. Environ., 140, 155-163, https://doi.org/10.1016/j.agee.2010.11.022, 2011.

Oenema, O., Velthof, G. L., Yamulki, S., and Jarvis, S. C.: Nitrous oxide emissions from grazed grassland, Soi Use Manage., 13, 288-295, https://doi.org/10.1111/j.14752743.1997.tb00600.x, 1997.

O'Hara, G. W. and Daniel, R. M.: Rhizobial denitrification: A review, Soil Biol. Biochem., 17, 1-9, https://doi.org/10.1016/00380717(85)90082-3, 1985

Paustian, K., Lehmann, J., Ogle, S., Reay, D., Robertson, G. P., and Smith, P.: Climate-smart soils, Nature, 532, 49-57, https://doi.org/10.1038/nature17174, 2016.

Phelan, P., Moloney, A. P., McGeough, E. J., Humphreys, J., Bertilsson, J., O'Riordan, E. G., and O'Kiely, P.: Forage legumes for grazing and conserving in ruminant production systems, Crit. Rev. Plant Sci., 34, 281-326, https://doi.org/10.1080/07352689.2014.898455, 2015.

Rafique, R., Anex, R., Hennessy, D., and Kiely, G.: What are the impacts of grazing and cutting events on the $\mathrm{N}_{2} \mathrm{O}$ dynamics in humid temperate grassland?, Geoderma, 181-182, 36-44, https://doi.org/10.1016/j.geoderma.2012.03.006, 2012.
R Core Team: R: A language and environment for statistical computing, R Foundation for Statistical Computing, Vienna, Austria, available at: http://www.R-project.org/ (last access: 15 November 2017), 2016.

Rihm, B. and Achermann, B.: Critical Loads of Nitrogen and their Exceedances. Swiss contribution to the effects-oriented work under the Convention on Long-range Transboundary Air Pollution (UNECE), Environmental studies, Federal Office for the Environment, Bern, 2016.

Rochette, P. and Janzen, H. H.: Towards a revised coefficient for estimating $\mathrm{N}_{2} \mathrm{O}$ emissions from legumes, Nutr. Cycl. Agroecosys. 73, 171-179, https://doi.org/10.1007/s10705-005-0357-9, 2005.

Rogiers, N., Eugster, W., Furger, M., and Siegwolf, R.: Effect of land management on ecosystem carbon fluxes at a subalpine grassland site in the Swiss Alps, Theor. Appl. Climatol., 80, 187203, https://doi.org/10.1007/s00704-004-0099-7, 2005.

Rosen, A. and Ljunggren, H.: Denitrification by Rhizobium meliloti. Field and laboratory studies with soil, Swed. J. Agr. Res., 26, 153-160, 1996.

Roth, K.: Bodenkartierung und GIS-basierte Kohlenstoffinventur von Graslandböden, Diploma Thesis, University of Zurich, 2006.

Rudaz, A. O., Wälti, E., Kyburz, G., Lehmann, P., and Fuhrer, J.: Temporal variation in $\mathrm{N}_{2} \mathrm{O}$ and $\mathrm{N}_{2}$ fluxes from a permanent pasture in Switzerland in relation to management, soil water content and soil temperature, Agr. Ecosyst. Environ., 73, 83-91, https://doi.org/10.1016/S0167-8809(99)00005-5, 1999.

Schmeer, M., Loges, R., Dittert, K., Senbayram, M., Horn, R., and Taube, F.: Legume-based forage production systems reduce nitrous oxide emissions, Soil Till. Res., 143, 17-25, https://doi.org/10.1016/j.still.2014.05.001, 2014.

Sieber, R., Hollenstein, L., Odden, B., and Hurni, L.: From classic atlas design to collaborative platforms - The SwissAtlasPlatform Project, in: From classic atlas design to collaborative platforms, International Cartographic Association, Paris, 2011.

Šimek, M., Elhottová, D., Klimeš, F., and Hopkins, D. W.: Emissions of $\mathrm{N}_{2} \mathrm{O}$ and $\mathrm{CO}_{2}$, denitrification measurements and soil properties in red clover and ryegrass stands, Soil Biol. Biochem., 36, 9-21, https://doi.org/10.1016/j.soilbio.2003.08.010, 2004.

Sintermann, J., Ammann, C., Kuhn, U., Spirig, C., Hirschberger, R., Gärtner, A., and Neftel, A.: Determination of field scale ammonia emissions for common slurry spreading practice with two independent methods, Atmos. Meas. Tech., 4, 1821-1840, https://doi.org/10.5194/amt-4-1821-2011, 2011.

Skinner, C., Gattinger, A., Muller, A., Mäder, P., Fliebach, A., Stolze, M., Ruser, R., and Niggli, U.: Greenhouse gas fluxes from agricultural soils under organic and non-organic management A global meta-analysis, Sci. Total Environ., 468-469, 553-563, https://doi.org/10.1016/j.scitotenv.2013.08.098, 2014.

Smith, K. A., McTaggart, I. P., and Tsuruta, H.: Emissions of $\mathrm{N}_{2} \mathrm{O}$ and $\mathrm{NO}$ associated with nitrogen fertilization in intensive agriculture, and the potential for mitigation, Soil Use Manage., 13, 296304, https://doi.org/10.1111/j.1475-2743.1997.tb00601.x, 1997.

Smith, P., Martino, D., Cai, Z., Gwary, D., Janzen, H., Kumar, P., McCarl, B., Ogle, S., O’Mara, F., Rice, C., Scholes, B. Sirotenko, O., Howden, M., McAllister, T., Pan, G., Romanenkov, V., Schneider, U., Towprayoon, S., Wattenbach, M., and Smith, J.: Greenhouse gas mitigation in agriculture, Philos. T. R. Soc. B, 363, 789-813, https://doi.org/10.1098/rstb.2007.2184, 2008. 
Snyder, C. S., Bruulsema, T. W., Jensen, T. L., and Fixen, P. E.: Review of greenhouse gas emissions from crop production systems and fertilizer management effects, Agr. Ecosyst. Environ., 133, 247-266, https://doi.org/10.1016/j.agee.2009.04.021, 2009.

Suter, M., Connolly, J., Finn, J. A., Loges, R., Kirwan, L., Sebastià, M.-T., and Lüscher, A.: Nitrogen yield advantage from grasslegume mixtures is robust over a wide range of legume proportions and environmental conditions, Glob. Change Biol., 21, 2424-2438, https://doi.org/10.1111/gcb.12880, 2015.

Tubiello, F. N., Salvatore, M., Ferrara, A. F., House, J., Federici, S., Rossi, S., Biancalani, R., Condor Golec, R. D., Jacobs, H., Flammini, A., Prosperi, P., Cardenas-Galindo, P., Schmidhuber, J., Sanz Sanchez, M. J., Srivastava, N., and Smith, P.: The contribution of agriculture, forestry and other land use activities to global warming, 1990-2012, Glob. Change Biol., 21, 26552660, https://doi.org/10.1111/gcb.12865, 2015.

Unkovich, M.: Measuring plant-associated nitrogen fixation in agricultural systems, Australian Centre for International Agricultural Research (ACIAR), Canberra, 2008.

van Groenigen, J. W., Velthof, G. L., Bolt, F. J. E. van der, Vos, A., and Kuikman, P. J.: Seasonal variation in $\mathrm{N}_{2} \mathrm{O}$ emissions from urine patches: Effects of urine concentration, soil compaction and dung, Plant Soil, 273, 15-27, https://doi.org/10.1007/s11104-004-6261-2, 2005.

Vellinga, T. V., de Haan, M. H. A., Schils, R. L. M., Evers, A., and van den Pol-van Dasselaar, A.: Implementation of GHG mitigation on intensive dairy farms: Farmers' preferences and variation in cost effectiveness, Livest. Sci., 137, 185-195, https://doi.org/10.1016/j.livsci.2010.11.005, 2011.

Vickers, D. and Mahrt, L.: Quality control and flux sampling problems for tower and aircraft data, J. Atmos. Ocean. Tech., 14, 512526, 1997.

Virkajärvi, P., Maljanen, M., Saarijärvi, K., Haapala, J., and Martikainen, P. J.: $\mathrm{N}_{2} \mathrm{O}$ emissions from boreal grass and grass - clover pasture soils, Agr. Ecosyst. Environ., 137, 59-67, https://doi.org/10.1016/j.agee.2009.12.015, 2010.

Wagner-Riddle, C., Hu, Q. C., van Bochove, E., and Jayasundara, S.: Linking nitrous oxide flux during spring thaw to nitrate denitrification in the soil profile, Soil Sci. Soc. Am. J., 72, 908-916, https://doi.org/10.2136/sssaj2007.0353, 2008.
Webb, E. K., Pearman, G. I., and Leuning, R.: Correction of flux measurements for density effects due to heat and water vapour transfer, Q. J. Roy. Meteor. Soc., 106, 85-100, https://doi.org/10.1002/qj.49710644707, 1980.

Weisser, W. W., Roscher, C., Meyer, S. T., Ebeling, A., Luo, G., Allan, E., Beßler, H., Barnard, R. L., Buchmann, N., Buscot, F., Engels, C., Fischer, C., Fischer, M., Gessler, A., Gleixner, G., Halle, S., Hildebrandt, A., Hillebrand, H., de Kroon, H., Lange, M., Leimer, S., Le Roux, X., Milcu, A., Mommer, L., Niklaus, P. A., Oelmann, Y., Proulx, R., Roy, J., Scherber, C., Scherer-Lorenzen, M., Scheu, S., Tscharntke, T., Wachendorf, M., Wagg, C., Weigelt, A., Wilcke, W., Wirth, C., Schulze, E.-D., Schmid, B., and Eisenhauer, N.: Biodiversity effects on ecosystem functioning in a 15-year grassland experiment: Patterns, mechanisms, and open questions, Basic Appl. Ecol., 23, 1-73, https://doi.org/10.1016/j.baae.2017.06.002, 2017.

Wilks, D. S.: Statistical Methods in the Atmospheric Sciences, Vol. 100, 3rd Edn., Academic Press, Amsterdam, 2011.

Wolf, B., Merbold, L., Decock, C., Tuzson, B., Harris, E., Six, J., Emmenegger, L., and Mohn, J.: First on-line isotopic characterization of $\mathrm{N}_{2} \mathrm{O}$ above intensively managed grassland, Biogeosciences, 12, 2517-2531, https://doi.org/10.5194/bg-12-25172015, 2015.

Wood, S.: Fast stable restricted maximum likelihood and marginal likelihood estimation of semiparametric generalized linear models, J. R. Stat. Soc. B, 73, 3-36, https://doi.org/10.1111/j.14679868.2010.00749.x, 2011.

Wood, S. N.: On confidence intervals for generalized additive models based on penalized regression splines, Aust N. Z. J. Stat., 48, 445-464, https://doi.org/10.1111/j.1467842X.2006.00450.x, 2006.

Zeeman, M. J., Hiller, R., Gilgen, A. K., Michna, P., Plüss, P., Buchmann, N., and Eugster, W.: Management and climate impacts on net $\mathrm{CO}_{2}$ fluxes and carbon budgets of three grasslands along an elevational gradient in Switzerland, Agr. Forest Meteorol., 150, 519-530, https://doi.org/10.1016/j.agrformet.2010.01.011, 2010 . 